UNIVERSIDADE DE BRASÍLIA

FACULDADE DE ECONOMIA, ADMINISTRAÇÃO, CONTABILIDADE E CIÊNCIA DA INFORMAÇÃO E DOCUMENTAÇÃO - FACE

DEPARTAMENTO DE CIÊNCIA DA INFORMAÇÃO E DOCUMENTAÇÃO - CID

CURSO DE GRADUAÇÃO EM BIBLIOTECONOMIA

PRISCILA DE MELO SILVA - 04/18889

\title{
PROMOVENDO E DISSEMINANDO COLEÇÕES ESPECIAIS
}


PRISCILA DE MELO SILVA

\title{
PROMOVENDO E DISSEMINANDO COLEÇÕES ESPECIAIS
}

\begin{abstract}
Monografia de conclusão de curso apresentada ao Departamento de Ciência da Informação e Documentação da Universidade de Brasília como requisito a obtenção de título de bacharel em Biblioteconomia, sob a orientação da Prof ${ }^{\mathrm{a}}$. Dra ${ }^{\mathrm{a}}$. Dulce Maria Baptista.
\end{abstract}

BRASÍLIA - 2009 
Silva, Priscila de Melo.

Promovendo e disseminando coleções especiais / Priscila de Melo Silva. Orientadora: Dulce Maria Baptista. - Monografia (graduação) Universidade de Brasília, Departamento de Ciência da Informação e Documentação, 2009.

1. Biblioteca - coleções especiais. 2. Disseminação - coleções especiais. 3. Sites -bibliotecas. 


\section{Agradecimentos}

Agradeço sempre, e muito, a Deus, pelas inúmeras e constantes oportunidades de crescimento e aprendizagem, que incluem essa - a de elaborar um trabalho assim. Agradeço a paz constante e a amizade que ele me oferece.

Agradeço aos meus pais, pelo amor e afeto sem medidas, pela paciência e pelo apoio. Agradeço, em especial, ao meu pai, por ser tão prestativo; e à minha mãe, por ser amorosa e atenciosa, e pela ajuda inestimável na revisão do texto deste trabalho.

Agradeço à minha irmã, Alice, por tudo, até pelas broncas. A ela devo muito do que sou, e, consequentemente, muito do que este trabalho se tornou.

À professora Dulce, que primeiro me aceitou como sua orientanda, acreditando em mim e em minhas idéias, e que foi atenciosa em meio a seus tantos afazeres, atendendo-me e muito me ajudando. A ela agradeço, também, as conversas agradáveis e os muitos ensinamentos, ao longo não só desse semestre último, mas também de todo o curso.

À Luíza Félix, que muito me ajudou na fase inicial deste trabalho. Agradeço a ela a paciência e a amizade que demonstrou, o auxílio com o primeiro levantamento e revisão das fontes, além da ajuda com as observações in loco.

À professora Sonia Bôeres, por ter me permitido trabalhar com este tema durante as aulas da disciplina Organização do Trabalho Intelectual, o que muito me auxiliou no adiantamento da revisão de literatura, bem como na melhor compreensão do objeto de pesquisa.

Agradeço aos bibliotecários da equipe de Referência da Biblioteca Central da Universidade de Brasília, pela ajuda com pesquisas, levantamento de fontes e normalização e por estarem sempre disponíveis. E, também, pelas conversas descontraídas e agradáveis, que sempre me foram restauradoras em meio ao cansaço dessa fase final.

Aos meus colegas da Diretoria de Documentação do Superior Tribunal Militar, meu local de estágio durante o último ano da graduação, pela amizade e pela compreensão e paciência quando precisei.

À minha amiga Mariana Giubertti, pela grande ajuda que me ofereceu, sendo tão prestativa, e também por ser atenciosa e amorosa. Agradeço especialmente por ter, tantas vezes, dado cobertura na escala da guarda de livros em nosso estágio.

À minha amiga Mariana Gomes, pela amizade de sempre, e a seus pais, Décio e Sandra, que sempre me recebem em sua casa com carinho e a quem devo momentos de muita alegria. 
Às amigas Sandra Cláudia e Noélia, pela amizade e por tudo que me ensinaram ao longo desses anos em que Brasília tornou-se minha casa.

Á Marjorie Fernandes pelo auxílio com as correções e normalização e também pela presteza. Seu olhar clínico e profissional muito me impressionou.

Ao Roberto Dantas, o Bob, muito agradeço por tudo. Agradeço pela atenção e pela compreensão de sempre, pelo carinho e pelo afeto, por ter aparecido em um momento tão propício e por ter se tornado uma pessoa de tamanha importância.

Ao Fernando Silva e à professora Miriam Manini, que aceitaram participar de minha banca, despendendo tempo, atenção e energia. A eles dedico minha admiração e honra pela convivência. 
"Às vezes, o usuário desconhece as possibilidades, a mera existência das fontes alternativas; é importante mostrá-las" Jalver Bethônico 


\section{Resumo}

A presente pesquisa pretende compreender melhor o tema das coleções especiais. Busca explorar e ampliar a visão sobre o que é especial dentro da instituição biblioteca, analisar experiências relativas às coleções especiais e investigar instrumentos para a promoção e disseminação dessas coleções.

Palavras-chave: Biblioteca - coleções especiais. Disseminação - coleções especiais. Sites bibliotecas. 


\section{Sumário}

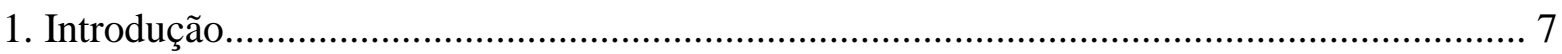

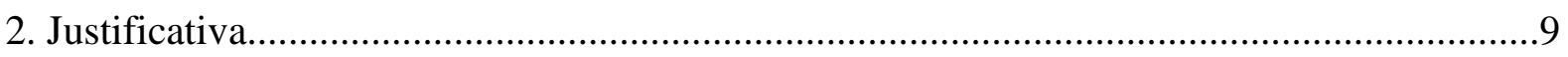

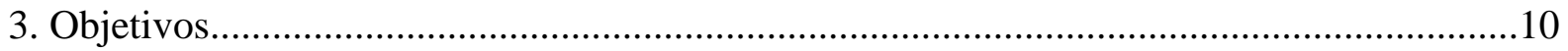

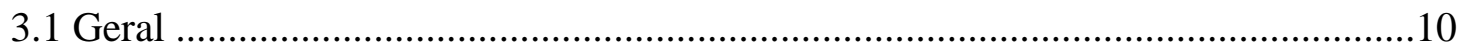

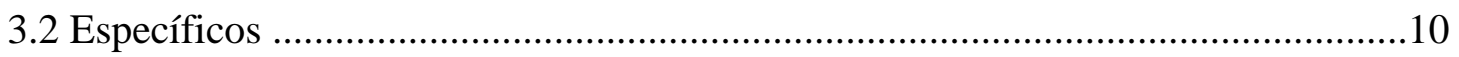

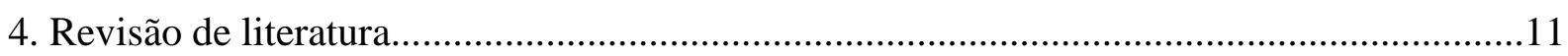

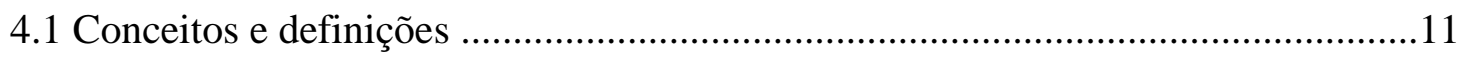

4.2 As coleções especiais na visão das Políticas de Desenvolvimento de

Coleções de algumas bibliotecas .............................................................................. 22

4.3 Algumas experiências e visões de promoção e disseminação

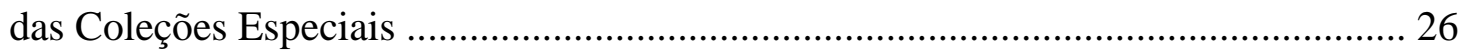

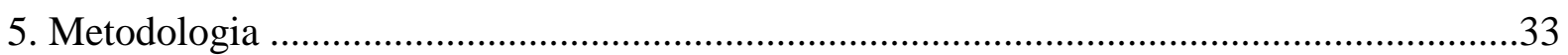

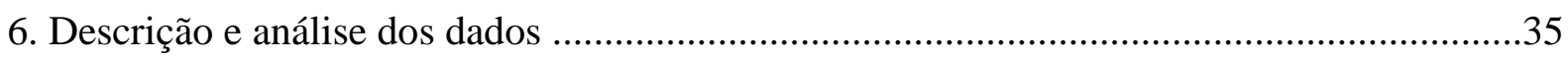

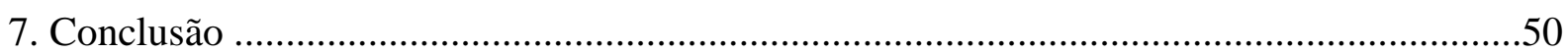

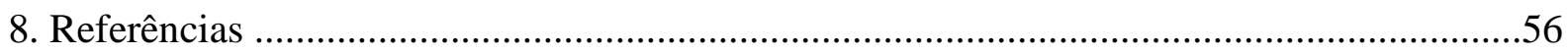




\section{Introdução}

No contexto da Sociedade da Informação, a disponibilização, a recuperação e o acesso a fontes de informação são ações corriqueiras, mas imprescindíveis no cotidiano de todo tipo de pessoas. Nesse sentido, a biblioteca é importante mediadora dessas ações.

Em alguns momentos desacreditada nos últimos anos, com o advento de novas tecnologias e possibilidades de uso da informação, a biblioteca teve sua morte decretada algumas vezes, e também a de seus serviços e funções. A necessidade de mudanças e adaptações é sempre presente, tendo em vista os avanços e as novas exigências provenientes deles, e são muito positivas para a melhoria dos serviços e abrangência da presença da biblioteca na vida das pessoas. No entanto, ela continua presente e viva, e importante instituição social de disseminação de informação, sendo, inclusive, única no oferecimento de alguns serviços e produtos.

Uma das possibilidades oferecidas pela biblioteca é o acesso ao livro e a outros tipos de documentos, não apenas como fontes de informação, mas como fatores de formação cultural. Dentre esses documentos, alguns se destacam pelas informações que oferecem e/ou pela maneira como oferecem, tornando-se muitíssimo importantes para pesquisadores, estudantes, simples curiosos. A importância de se preservar tais documentos é grande, para que o seu acesso continuado possa ser garantido. E também é grande a importância de se garantir e disseminar esse acesso, promovendo a existência desses documentos, bem como maneiras de se aproximar e usufruir deles.

Esses documentos são reconhecidos dentro das bibliotecas como especiais, e, reunidos, formam as chamadas coleções especiais. Há muitas maneiras de se compreender um documento como especial, e tais maneiras serão analisadas neste trabalho. De modo geral, as coleções especiais são aquelas que diferem do acervo geral de livre circulação e dos serviços primários oferecidos pela biblioteca, ou seja, do fluxo geral e comum de informação dentro dela, com ele coexistindo e o complementando.

Preocupou-se aqui em revisar a literatura que tratasse daquilo que era especial nas bibliotecas, com o objetivo de compreender afinal o que era considerado especial, transformar e solidificar a vaga idéia que se tem sobre aquilo que é especial quando, por exemplo, iniciase uma conversa sobre o assunto. $\mathrm{O}$ objetivo não foi o de definir, o de criterizar exatamente, mas o de explorar para se transformar e ampliar a noção que se tem sobre o que é especial dentro da instituição biblioteca. 
Também se procurou fazer um estudo exploratório para melhor compreender as coleções especiais, bem como de possíveis meios para as promover e disseminar. Nesse estudo, foram feitas algumas observações in loco em bibliotecas do Distrito Federal escolhidas por possuírem coleções especiais. Uma viagem por páginas na web de bibliotecas que possuíssem coleções especiais em seus acervos também foi realizada como parte dessa exploração, procurando observar como as coleções ganham espaço nessas páginas, como são entendidas pelas bibliotecas e como essas páginas podem servir como instrumento de promoção das coleções. Uma compilação de outros desses instrumentos, observados ao longo do semestre em que este trabalho foi realizado, fazem parte desse estudo exploratório. A metodologia utilizada encontra-se melhor apresentada mais adiante.

As coleções especiais compõem verdadeiros tesouros, não apenas por suas características intrínsecas, mas pelas características novas que podem proporcionar para leituras, para a produção do conhecimento, e mesmo para um novo olhar diante de fatos, coisas e do próprio mundo. Compreendê-las, tomando tempo em olhar e analisar visões a seu respeito, bem como explorar meios de torná-las mais visíveis ao público, partindo-se da idéia que se tem de sua importância, foi o que se tentou fazer neste trabalho.

Este estudo se apresenta como o início de uma tentativa de se focalizar o assunto e melhor defini-lo como campo de pesquisa, bem como de melhor entender um tema pouco tratado ao longo do curso de graduação em Biblioteconomia. 


\section{Justificativa}

Este trabalho se justifica, primeiramente, pela escassez de estudos sobre o tema das coleções especiais e, em particular, sobre instrumentos para a sua disseminação e promoção. Além disso, para esta pesquisadora, o tema escolhido é de grande relevância pelo caráter de importância informacional e cultural dos acervos especiais, os quais reclamam por pesquisas e discussões que os tomem como objeto.

Tratar da promoção é uma tarefa urgente a se cumprir. Mais do que urgente, é imprescindível. Todavia, esta decorrerá da compreensão primeira do valor das coleções propriamente ditas, tanto por parte dos profissionais, quanto dos usuários. As ações de promoção muito contribuem para a melhoria e visibilidade de certos aspectos relacionados aos documentos e à informação. Por isto, neste trabalho se procura investigar, primeiramente, o que são as coleções especiais e lhes dedicar um olhar no sentido de entender o seu valor e, consecutivamente, estudar os instrumentos que lhes pode dar visibilidade, bem como torná-las acessíveis.

Considerando-se a realidade atual, que se fundamenta na visão da Sociedade da Informação, uma pesquisa do teor que esta apresenta é necessária visto que trata de fontes de informação. As coleções especiais representam tais fontes e de maneira diferenciada, seja pelo seu valor histórico, seja pela representatividade para alguma área do conhecimento ou por transmitirem a informação de um modo diferente do convencional. Cuidar do modo como elas podem se tornar visíveis e acessíveis dentro do contexto atual é necessário em vista das novas possibilidades tecnológicas. Nesse sentido, este trabalho representa uma disposição para o envolvimento nas discussões que, sob novas perspectivas, retomam a questão. 


\section{Objetivos}

3.1 Geral

Contribuir ao melhor conhecimento das questões referentes às coleções especiais abrigadas em bibliotecas.

\subsection{Específicos}

3.2.1 Revisar a literatura que trata de conceituar coleções especiais;

3.2.2 Compreender o que algumas instituições consideram como coleções especiais;

3.2.3 Observar e analisar a maneira como algumas instituições lidam na prática com suas coleções especiais;

3.2.4 Enumerar e avaliar instrumentos de disseminação e promoção das coleções especiais. 


\section{Revisão de literatura}

Em função da abrangência do tema, a revisão de literatura contemplou os seguintes tópicos: Conceitos e definições; As coleções especiais nas visões das Políticas de Desenvolvimento de Coleções de algumas bibliotecas e Algumas experiências de promoção e disseminação. No primeiro tópico, procurou-se revisar a literatura que tratasse de esclarecer em que consistem as coleções especiais e os materiais de que são compostas. No segundo, procurou-se compreender como são vistas as coleções por diferentes bibliotecas, revisando seus documentos de Políticas de Desenvolvimento de Coleções, o que serviu para complementar o primeiro tópico, bem como dar abrangência à visão que se construiu neste trabalho sobre as coleções especiais. O terceiro procura revisar a literatura que trata de experiências relacionadas às coleções especiais, especialmente no sentido de as promover e tornar disponíveis ao público. Tais experiências foram publicadas em eventos da área da Biblioteconomia ou de áreas afins, ou foram publicadas em formato de artigo, ou estão expostas em páginas da Internet.

\subsection{Conceitos e definições}

Em qualquer instituição que se responsabilize por armazenar e disseminar informações há a formação de uma coleção - uma reunião de um conjunto de documentos com alguma semelhança entre si. Para Milanesi (2002, p. 9), o pensamento humano "encontra suas formas de registro", os quais - a produção e a memória humanas - são administrados por pessoas especializadas em preservar e organizar, de tal forma que a menor unidade possa ser perfeitamente localizável, exercendo as ações de "buscar-o-que-foi-guardado e de guardar-oque-foi-registrado". E o ajuntamento dos registros em um único lugar para facilitar a ordenação e o acesso é, segundo o autor, o que se pode chamar de coleção. Havendo registros, haverá sempre uma coleção, "porque os homens precisam repartir o pensamento criado, disseminando-o para garantir a posse do conhecimento".

Em meio a todas as coleções formadas pelos registros do pensamento humano, há aquelas que se diferenciam das demais por algum motivo. Essas coleções ganham destaque dentre as demais e têm sido chamadas de Coleções Especiais. 
Definir o que seja afinal o significado de tal nomenclatura é tarefa complicada. Para Alice Prochaska "é absolutamente impossível definir o que significa 'coleções especiais’ [...]. Já é difícil entender culturas diferentes. Imagine a dificuldade de entender, dentro de nossas bibliotecas, que cada biblioteca define coleções especiais de maneiras diferentes". De fato, qualquer característica pode ser especial em um documento - um suporte onde se registrou o pensamento humano - qualquer pequeno detalhe pode torná-lo especial. O julgamento e a opinião emitidos por alguém em algum momento sobre o que é ou não especial é o que, enfim, torna um documento, ou um conjunto de documentos, merecedores ou não do título especial.

As coleções especiais diferem do acervo geral ou do acervo de referência por características únicas. Segundo Nardino e Caregnato (2005), as coleções especiais são obras que se destacam de alguma maneira, por certas peculiaridades, independentemente da época em que foram criadas. Sendo assim, elas constituem uma boa fonte de pesquisa e conhecimento.

De acordo com o Dicionário Aurélio (1995), o verbete especial é definido como: relativo a uma espécie, próprio, específico, particular, fora do comum, distinto, excelente, exclusivo, reservado. O Michaelis (1998), por sua vez, define-o como: peculiar de uma coisa ou pessoa, exclusivo, fora do comum, excelente, notável, superior, distinto. Mas que critérios são comumente utilizados para que se intitule como especial um documento ou uma coleção de documentos? Em que se baseia o julgamento de um especialista ou profissional no momento da tomada dessa decisão?

Inicialmente, tudo o que se diferencia de alguma maneira do livro pode ser considerado especial. No âmbito das bibliotecas, que tradicionalmente se acostumaram com a imagem do livro como principal fim de sua rotina, de modo geral tudo se classifica (ou se classificou) a partir do livro, ou em função dele.

Definir, portanto, o que seja o livro é importante para que se possa definir o que é especial. Fonseca explica que "a etimologia da palavra livro indica o material com que se fabricava o papel na Antiguidade, isto é, entrecasca de certos vegetais que, transformada em pasta, adquire a forma laminada". Por causa dessa etimologia o livro é, segundo o autor, corriqueiramente definido como uma reunião de cadernos de papel contendo texto manuscrito ou impresso (FONSECA, 2007, p. 21).

\footnotetext{
${ }^{1}$ Declaração verbal proferida por Alice Prochaska, bibliotecária da Sterling Memorial Library, na Yale University, durante a reunião do Conselho de Membros da OCLC em 2008. A referência completa encontra-se na lista ao final do trabalho. Procurar pelo autor "OCLC".
} 
O Glossário de Termos Biblioteconômicos (2009) define o livro como

Conjunto de cadernos, manuscritos ou impressos, cosidos ordenadamente e formando um bloco; documento impresso, não periódico, com mais de 48 páginas, sem contar as da capa, que constitui uma unidade bibliográfica; monografia; obra científica ou literária que forma ou pode formar um volume.

O Glossário Geral de Ciência da Informação do Departamento de Ciência da Informação e Documentação da Universidade de Brasília (2009) afirma que livro é

uma publicação não periódica que consiste, materialmente, na reunião de folhas impressas e organizadas em cadernos, que presos por um dos lados mediante costura e cola, recebem uma capa flexível e rígida.

E ainda:

Qualquer publicação que não seja seriada. É geralmente a respeito de um só assunto ou assuntos relacionados e se completa por si mesma, ainda que esteja organizada em capítulos, sessões ou partes.

Outra definição é:

Publicação impressa, não periódica, contendo, no mínimo, quarenta e nove páginas, excluindo-se a capa.

O Glossário da disciplina História do Livro e das Bibliotecas do curso de Biblioteconomia da UnB define o livro como sendo

Volume transportável, composto por páginas, sem contar as capas, encadernadas, contendo manuscrito ou impresso, e/ou imagem(ns) e que forma uma publicação unitária (ou foi concebido como tal) ou parte principal de um trabalho literário, científico ou outro. (BAPTISTA, 2008)

O primeiro material a ser diferenciar do livro, como ficou conhecido, talvez tenha sido o periódico. Os periódicos surgiram no século XVII "como uma evolução do sistema particular e privado de comunicação que era feito por meio de cartas entre os investigadores e das atas ou memórias das reuniões científicas" (STUMPF, 1996, p. 384). Os periódicos consolidaram-se como o novo meio para a comunicação científica no século XIX, quando ganharam, enfim, credibilidade, inclusive para substituir os livros. "Os artigos, até aquela época, eram considerados como formas provisórias de comunicação, sendo sempre a forma 
monográfica de livros impressos a preferida para o registro definitivo da ciência" (Idem, p. 384). Os periódicos passaram a ser preferidos no momento da publicação e comunicação científica por dois motivos: a demora para a publicação de monografias, o que ia contra o caráter prioritário das descobertas científicas, e a onerosidade de sua impressão

A publicação periódica trouxe mudanças nas rotinas dos que liam, dos que escreviam e, também, dos que armazenavam, processavam e disseminavam. O crescimento do número de publicações periódicas foi exponencial desde o surgimento da primeira revista, o Journal des Sçavants.

No século XX, o crescimento permaneceu acentuado, devido ao fato das revistas passarem a ser publicadas, também, por editores comerciais, pelo Estado e por universidades. A partir da segunda metade, especialmente, as publicações seriadas tiveram um crescimento exponencial, intensificando também o seu controle bibliográfico (STUMPF, 1996, p. $385)$.

A mudança de alguns hábitos nas bibliotecas com o crescimento do número de periódicos acentuou as diferenças entre o livro e o periódico. Diante da visão consolidada que se tinha do livro, o periódico apresentou-se como um tipo de documento diferente, distinto, sendo, muitas vezes, alocado em local separado e se tornando o centro de mudanças administrativas e técnicas.

O periódico é definido pelo Glossário de Termos Biblioteconômicos (2009) como "obra ou publicação que aparece em tempos determinados; que se renova em tempos fixos ou determinados. Publicação periódica”. Já o Glossário Geral de Ciência da Informação (2009a) define-o como "publicação, numerada consecutivamente, publicada, geralmente em intervalos regulares, cujo conteúdo variado se refere a notícias, informes de atividades e artigos, de vários colaboradores".

Outros materiais que se distinguem do livro de alguma maneira são os chamados materiais especiais. Em princípio, todo material que difere dos livros, folhetos e periódicos e suporta, armazena, alguma informação (podendo, assim, ser qualificado como documento) é um material especial.

Do ponto de vista da disciplina de Formação de Coleções, a aquisição e a seleção de materiais especiais se dão de uma maneira diferente da dos demais materiais. Para Vergueiro (1995), no âmbito da seleção de documentos, os materiais especiais são todos, à exceção do livro. O autor, dessa maneira, considera como especiais os periódicos (inclusive os jornais), as histórias em quadrinhos, os materiais audiovisuais (filmes, discos, fitas cassetes, 
diapositivos), as novas tecnologias (CDs, softwares, disquetes), as microformas, as transparências, as fotografias, os brinquedos, os incunábulos, entre outros.

Andrade e Vergueiro (1996) entendem que algumas obras apresentam particularidades no que tange à prática da aquisição, afirmando que, no momento da compra, certos materiais devem receber atenção em relação às suas peculiaridades. Os autores consideram como casos especiais de compra:

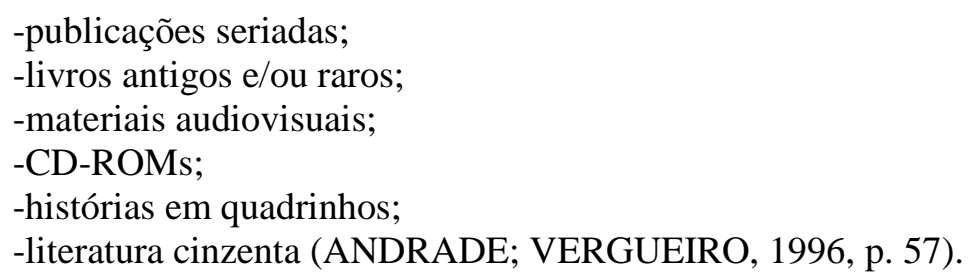

Além desses, outros materiais que se tornam especiais no momento da aquisição são, segundo os autores, os cartográficos, iconográficos, normas técnicas, partituras, microformas, catálogos de exposições, entre outros. Os mesmos materiais que Vergueiro (1995) chama de especiais são tratados por Perota (1997) como não-bibliográficos, em função das definições que lhes são dadas na segunda edição do Código de Catalogação Anglo-Americano (AACR2).

Os materiais não-bibiográficos são, portanto, os documentos iconográficos, os sonoros, as imagens em movimento, os recursos eletrônicos, os documentos cartográficos, a música impressa, as microformas, os artefatos tridimensionais e reália, que Perota passa a definir. O arquivo de computador é "um conjunto de informações codificadas para manipulação por computador" (PEROTA, 1997, p.13). Cita-se, como exemplos, as fitas e discos magnéticos. De acordo com as últimas mudanças no AACR2, reconhece-se esse tipo de documento como arquivos de dados legíveis por máquina. Já os artefatos tridimensionais "são objetos fabricados a mão ou industrialmente pelo homem, tais como: jogos, modelos, esculturas, objetos para exposições, máquinas, medalhas, moedas e armas". E as reálias "são objetos que se encontram na natureza, objetos reais e autênticos, como por exemplo, espécimes botânicas e zoológicas" (Idem, p. 23). Os filmes são definidos pela autora como "uma reprodução em miniatura de uma imagem ou outro material gráfico, o qual não pode ser utilizado sem ampliação. Apresenta-se contendo uma sucessão de imagens projetadas para serem vistas, figura por figura, com ou sem som.

Os materiais cartográficos são especificados pela autora como sendo os mapas, as cartas, os globos e os atlas, e os materiais iconográficos são: "imagens em duas dimensões, opacas, tais como originais ou reproduções de arte, quadros, gravuras, selos, fotografias, 
desenhos artísticos ou técnicos; imagens transparentes (destinadas à projeção para serem vistas) tais como, diapositivos (slides), radiografias, transparências" (Ibidem, p. 109).

São ainda tipificados os materiais iconográficos mais comuns nas bibliotecas e centros de informação como sendo os cartões postais, os diapositivos, a filatelia, as fotografias, as gravuras, os cartazes, as ilustrações, os originais de arte, as reproduções de arte e as transparências.

Uma microforma é definida pela autora como "uma reprodução feita fotograficamente, ou por outros meios, em material transparente ou opaco, em dimensões muito reduzidas sendo a sua leitura impossível a olho nu" (PEROTA, p. 145). As microformas podem ser publicações originais ou reproduções de outros tipos de materiais. São muito utilizadas em bibliotecas principalmente para a preservação de informações, com a vantagem da redução de espaço para alocação.

Segundo Milanesi (2002, p. 30) as microformas foram, em meados do século XX, imaginadas como uma saída para um problema gerado pela alta produção de textos: espaço para armazenamento.

A música impressa é indicada pela autora como sendo também um tipo de material não-bibliográfico. A definição para partitura pode ser compreendida como uma "série de pautas nas quais estão escritas todas as partes instrumentais e/ou vocais de uma obra musical [...]" (PEROTA, 1997, p. 165).

É importante compreender os materiais acima descritos como de importância e destaque dentre os demais tipos de acervos, especialmente porque todos os processos biblioteconômicos relacionados a eles possuem peculiaridades, desde a seleção e a aquisição até o empréstimo. A autora os nomeia como Multimeios e compreende a cada um como item especial no acervo.

Também tratando de materiais não-bibliográficos, Ferreira descreve fatos e detalhes históricos sobre a documentação de publicações oficiais não-bibliográficas e propõe soluções para o seu controle bibliográfico, definindo-os, conforme nomenclatura em língua inglesa, como nonbook, nonprint ou audiovisual. A autora relata que "nonbook material é expressão usada para designar todo e qualquer material, não incluído nas categorias livro, folheto e periódico e que requer tratamento especial" (FERREIRA, 1976, p. 232).

Já a expressão nonprint é explicada pela autora utilizando a designação de Jay E. Daily, que define esses materiais como aqueles "que não podem ser descritos pelas regras que são aplicadas aos livros e que requerem métodos especiais de aquisição, catalogação, uso e armazenagem". O termo audiovisual é "geralmente, reservado pelos autores estrangeiros para 
designar os materiais que exijam em sua utilização equipamento apropriado de som e/ou vídeo", mas é definido por alguns autores como sinônimo do nonbook, como na definição retirada da Encyclopedia of library and information science, citada por Ferreira e que estabelece como materiais audiovisuais "não apenas discos, filmes diapositivos, como também mapas, gráficos, modelos e ainda microformas e fitas de computador" (FERREIRA, 1976, p. 232-233).

A autora ainda ressalta que a expressão material especial tem sido utilizada para se referir ao mesmo tipo de documentos definido por ela como nonbook. Em certo parágrafo do texto, a autora explica que, em seu trabalho, a expressão audiovisual refere-se a todo e qualquer material não incluído nas categorias livro, folheto ou periódico.

Hamar e Germano (1970), propõem um índice de recursos audiovisuais, tipificando-os como filmes, diapositivos, diafilmes, fitas de gravação, microfilmes, transparências e video tapes.

No prefácio de seu A primer of non-book materials in libraries, Mason explica que a ênfase no uso de materiais não-livro, especialmente o microtext (microtexto), havia crescido nas bibliotecas durante a década anterior à publicação de seu livro, chamando, às vezes, esses materiais pelo nome de materiais especiais (special materials). São eles: os mapas, gravuras (illustrations), recortes de jornais e revistas (press cuttings), filmes $(35 \mathrm{~mm}$, lantern slides e stereoscopic slides), fotocópias (negativos, slides e cópias realizadas através do recurso da xerografia), microcópias (microfilmes, microfichas, microcartão, microprint- para impressão em offset) e gravações sonoras (gramafone, long-playing e fitas) (MASON, 1958).

Weihs, Lewis e Macdonald definem o termo media (mídia) como um termo genérico para designar vários tipos de novos suportes em proliferação, para evitar a multiplicação de designações, tais como:

audiorecord (includes sound recordings of all types, cylinder, disc, roll, tape, wire), chart (includes flip chart, wall chart), diorama, filmstrip (includes filmslip), flash card, game, globe, kit (two or more media wich are no fully interdependent and, therefore, may be used separately), machine readable data file (includes computer datacell, disc, drum, magnetic tape, paper tape, punched card, etc.), map (includes relief map), microform (includes aperture card, microfilm, microfiche, micro-opaque), microscope slide, model (includes mock-up), motion picture (includes kinescope recording, motion picture loop), picture (includes art original, art print, photograph, post card, poster, study print), realia (consists of specimens, samples, artifacts), slide (includes stereograph), transparency, videorecord (includes videocassette, videodisc, videotape, electronic video recording, etc. ${ }^{2}$ (WEIHS; LEWIS; MACDONALD, 1973, p. 7)

\footnotetext{
${ }^{2}$ Para alguns dos termos acima não foram encontradas expressões paralelas em língua portuguesa. Para evitar traduzir uns e manter outros na língua original, preferiu-se manter todos em língua inglesa.
} 
Collison (1957) nomeia de special materials aqueles materiais que se diferenciam dos livros, os non-books. São considerados pelo autor como materiais especiais: ilustrações, slides, negativos, fotografias, microfilmes, rolos de filmes, gravações sonoras, jornais e periódicos, clippings de periódicos, índices relativos a periódicos, panfletos, catálogos comerciais, mapas e filmes.

O Sistema Integrado de Bibliotecas da Universidade de São Paulo (SIBi-USP) considera como materiais especiais os suportes físicos da informação que seguem: "diapositivos, fitas de vídeo, filmes, imagens de satélites, modelos anatômicos, transparências, kits (som + imagem), fitas sonoras, discos, mapas, cartas, globos, fotografias, cartazes, diafilmes, partituras, materiais iconográficos, programas de computador" (UNIVERSIDADE..., 1998).

O SIBi-USP considera que livros e publicações periódicas armazenadas em suportes como disquete, CD-Roms, microformas e outros que não o papel não são materiais especiais, mas permanecem pertencendo a duas categorias: Periódicos e Livros e outros materiais nãoperiódicos. O documento também inclui as coleções especiais na categoria Livros e outros materiais não-periódicos.

Muitas bibliotecas reúnem em uma coleção esses materiais intitulados como multimeios, multimídia, audiovisuais, materiais especiais e materiais não-bibliográficos. Essas coleções de modo geral são administradas por uma divisão ou setor da biblioteca que se responsabiliza apenas por elas. As coleções de materiais especiais costumam ser alocadas em separado do acervo geral, por questões de conservação, acesso e segurança. Algumas vezes essa divisão está associada ou subordinada a uma divisão maior que se responsabiliza por vários tipos de coleções consideradas especiais, inclusive a de materiais especiais. As coleções de materiais especiais são consideradas, portanto, por muitas bibliotecas, como um tipo de coleção especial.

Quanto às obras raras - mencionadas acima como um tipo de material especial por se diferenciar do livro no momento da seleção e aquisição -, pode-se dizer que se diferenciam também por outros motivos. A maior parte das obras raras são, na verdade, livros, mas se diferenciam dos que circulam comumente no meio comercial/editorial e livremente na biblioteca, por possuírem características que os tornam valiosas e dificilmente substituíveis.

Os critérios utilizados para se classificar uma obra como rara têm sido objeto de estudo de muitos profissionais, mas, devido ao próprio caráter do livro raro, não é possível 
que se estabeleçam rigidamente tais critérios. A maior parte das instituições, portanto, desenvolve seus próprios critérios de raridade, tomando, por vezes, aqueles utilizados por outras instituições e consultando profissionais e pesquisadores envolvidos com o assunto.

Para Abatti (2006, p. 21) a idéia de obra rara está relacionada àquela que se tem do livro. Para a autora, o livro impresso é objeto vivo e de grande importância, que faz parte da história, tanto que "os mais antigos são tratados como jóias raras, ou melhor dizendo, como verdadeiras obras raras". Ela afirma que a raridade de um livro o torna relevante para a humanidade como um todo e patrimônio histórico-cultural representativo da memória local e mundial.

Rodrigues também considera que o livro e a obra rara são complementares, e ressalta a importância das obras raras a partir da importância do livro: "o livro na história da humanidade sempre foi um veículo de inovação. Mesmo na era da automação e da pesquisa em base de dados, a importância e a utilidade dessas obras raras são inequívocas" (RODRIGUES, 2006, p. 182).

Poder-se-ia dizer, numa primeira definição, que um livro antigo é, necessariamente, raro. Mas a característica de uma obra rara vai além de sua antiguidade, especialmente porque, segundo Carteri (apud ABATTI, 2006, p. 27), “existem milhões de livros antigos que nada valem porque não interessam a ninguém”. Pinheiro (apud SILVA, 2000, p.1) esclarece:

Obviamente, apenas a antigüidade de uma obra não caracteriza a sua raridade. Rara pode ser mesmo uma publicação da década de oitenta; mas sua antigüidade determina os peculiares aspectos bibliológicos da página de rosto - da sua inexistência à evolução de nossos dias; do colofão - do seu detalhamento à simplicidade atual; do título de partida e do título corrente; das licenças e das disposições de textos, em linha tirada, colunas ou corandel.

Nardino e Caregnato (2005, p. 383) comungam do pensamento de Pinheiro ao afirmarem que "para ser raro um livro não precisa necessariamente ser antigo, embora o critério de antiguidade seja o primeiro a ser considerado na identificação da obra rara". Segundo estas autoras, os critérios para definir a raridade de uma obra editada antes de 1860 podem ser: manuscritos anteriores à produção tipográfica; obras publicadas no século XV até o ano de 1801, período que compreende o início da tipografia artesanal até a produção industrial dos livros; obras produzidas na fase inicial da imprensa em qualquer lugar. No Brasil, por exemplo, são raras as obras publicadas no século XIX, a partir da criação da Imprensa Régia e as primeiras obras impressas de conjunto bibliográfico, como coleções de primeiros números de diversos periódicos. 
No entanto, ainda se deve levar em consideração as especificidades de cada biblioteca ou de cada centro especializado:

O que deve ser guardado como obra rara em cada biblioteca dependerá, assim, de onde ela se encontra e de seu propósito. Bibliotecas especializadas terão focos distintos, assim como o contexto regional poderá ser importante na formação de coleções. Em Brasília, são importantes os livros, panfletos e revistas publicados quando de sua inauguração este, aliás, será um dos focos das Coleções Especiais da Biblioteca Nacional de Brasília. A princípio, eles não se enquadrariam em nenhum dos critérios acima, pois foram editados em finais dos anos cinqüenta, início dos sessenta, mas são escassos e interessam especialmente à comunidade local. (REIFSCHNEIDER, 2008, p. 70-71).

Nardino e Caregnato (2005, p. 384), utilizando conceitos de Beatriz Marona Oliveira, categorizam as obras raras em: obras comprovadamente raras e obras circunstancialmente raras. As primeiras são aquelas que são raras devido ao seu limite histórico e cronológico, as segundas são as que se "enquadram em critérios preestabelecidos por instituições ou colecionadores, podendo não ser consideradas raras em outros contextos".

Os critérios utilizados por Souza, Bernardi e Bueno (2002, p. 59) na formação do acervo da Biblioteca de Obras Raras da Universidade São Francisco foram:

- relatos de viajantes estrangeiros dos séculos XVIII e XIX;

- obras jurídicas e teológicas dos séculos XVI a XIX;

- edições em diferentes suportes, personalizadase numeradas;

- obras esgotadas e desaparecidas;

- edições fac-similares;

- as primeiras edições de autores clássicos de diferentes áreas do conhecimento;

- edições censuradas;

- teses defendidas até o final do século XIX;

- periódicos estrangeiros e nacionais dos séculos XIX e primeiras décadas do século $\mathrm{XX}$;

- periódicos brasileiros técnico-científicos do mesmo período.

Muitos autores consideram que as coleções de obras raras sejam coleções especiais, sendo às vezes compreendidas como o único tipo de coleções especiais. Exemplos dessa compreensão podem ser conferidos nos trabalhos de Silva, Dib e Caamano (2003) e de Silva (2000).

Também é comum em algumas instituições, a confusão entre os exemplares que devem ir para a coleção de obras raras e aqueles que devem ser considerados parte de alguma outra coleção especial. Esse conflito de idéias ocorre não só pelo fato das obras raras serem 
comumente compreendidas como um tipo de coleção especial, mas também porque um exemplar sozinho daquela coleção pode ser raro, mas talvez a coleção inteira não o seja. Por exemplo: quando se diz que um exemplar é considerado raro e se leva em consideração o critério de vinculação com personagem cultural, histórico ou político, esta vinculação é identificada por anotações, dedicatórias, autógrafos ou marcas de posse, que seriam os ex libris. E aí, de acordo com Sant'Ana, (2001, p. 12), “a presença de um ex libris, por exemplo, só será significativa se a política de seleção da instituição determina que todas as obras da coleção que pertenceu a um antigo bibliófilo deverão ser mantidas reunidas no mesmo espaço; mesmo assim, é preferível chamar esta coleção de especial e não de rara”.

Alguns autores consideram que as obras especiais sejam aquelas que escaparam aos critérios que definem uma obra como rara, mas ainda assim possuem alguma característica que a torna especial. Segundo Carvalho e Val (2004, p. 4) as coleções especiais se distinguem das demais devido à natureza dos materiais que constituem seus documentos, o que os torna "únicos, escassos e raros, com valor no mercado livreiro ou valor como artefato e significado histórico", além dos fatores que envolvem sua aquisição e administração.

Para a formação de acervos temáticos e escolha de itens avulsos para formação de coleções especiais da Biblioteca Central da Universidade de Campinas-UNICAMP, Carvalho e Val (2004, p. 5) utilizam os seguintes critérios:

- Encadernações luxuosas;

- Obras iconográficas (ilustradas, volumes ou porta-fólios) contendo gravuras;

- Obras contendo mapas valiosos;

- Livros, folhetos, periódicos e mapas com significado comprovado;

- Livros de autores locais de particular interesse;

- Material que exige segurança (livros em formatos não comuns);

- Obras literárias, publicadas antes de 1930, no Brasil; que não foram reeditadas, no Brasil.

Dias e Pires (2003) definem as coleções especiais no âmbito de cada tipo de biblioteca/serviço de informação. Dentro da tipologia da biblioteca pública, as coleções especiais são definidas como “publicações governamentais (município/estado/federação), produção histórica e cultural local, coleções para deficientes (visuais), hemeroteca, coleções para minorias, etc" (DIAS; PIRES, 2003, p. 12).

Já para bibliotecas universitárias, as autoras definem as coleções especiais como “coleções de artes, publicações da universidade, produção científica, acervos de pesquisadores e professores" (Idem, p. 14). Para os demais tipos de bibliotecas/serviços de informação não são apontadas as coleções especiais nem sua especificação. Nos campos em que são definidas 
as tipologias das fontes de informação de cada tipo de biblioteca/serviço, aparecem muitas vezes as especificações: mapas, plantas, fotos, slides, obras de arte, atas, relatórios, maquetes, projetos, entre outros. Os materiais são distintos de acordo com o tipo de biblioteca/serviço em que estão alocados como parte do acervo. Um material se torna especial de acordo com a instituição onde fica disponível para uso e consulta: um material que é especial numa biblioteca pública é um material comum numa midiateca, por exemplo.

\subsection{As coleções especiais na visão das Políticas de Desenvolvimento de Coleções de algumas bibliotecas}

Em geral, o acervo de uma biblioteca possui vários níveis. Entende-se nível como parte do acervo formada a partir de objetivos de uso diferentes. É possível observar a divisão dos seguintes níveis em muitas instituições: didático, básico, de pesquisa, e outros. Algumas vezes, uma ou outra instituição considera como um dos níveis de seu acervo o das Coleções Especiais. Há, entretanto, instituições que não consideram as Coleções Especiais como um dos níveis de seu acervo, mas como um componente de algum nível. Nesse caso, a formação dessas coleções ainda é gerida a partir de um enfoque diferenciado.

Esses critérios podem ser estabelecidos tomando como base as necessidades dos usuários, tendo-se em mente a missão e a visão da biblioteca e considerando alguns objetivos específicos que ela possa ter - como o de ser uma instituição depositária de memória, por exemplo. Isso acontece devido à multidimensionalidade assumida pela biblioteca, que assume a informação para os usuários como sua principal atividade fim, mas também outras de cunho depositário, cultural e histórico. Tal multidimensionalidade é bela em muitos sentidos e apresenta muitas vantagens, mas pode conduzir a problemas no momento da formação de um acervo e das coleções que o compõem.

As saídas encontradas para esses problemas giram em torno do estabelecimento de critérios claros e objetivos para a formação do acervo como um todo, para cada um de seus níveis e para cada uma de suas coleções. Esses critérios são reunidos em um documento, denominado Política de Desenvolvimento de Acervos/Coleções, que cada biblioteca deve escrever de maneira independente. No momento da elaboração de sua política, um estudo detalhado dos usuários reais e potenciais da biblioteca é realizado, bem como uma revisão dos objetivos, missão e visão da biblioteca e da instituição à qual ela pertence, no caso de haver uma. Nesse documento são expressos os alvos da biblioteca referentes às coleções, tanto 
qualitativa quanto quantitativamente, e os critérios são discriminados de acordo com as particularidades dessas coleções, inclusive as Coleções Especiais.

Muitas bibliotecas não incluem entre suas coleções uma que seja especial ou diferenciada das demais. Em sua maior parte, essas bibliotecas dividem suas coleções entre básica e complementar.

A biblioteca da Faculdade Metropolitana de Belo Horizonte (2009) aplica, a partir de seu documento de política, critérios de seleção diferenciados para livros, periódicos, material de referência e multimeios, mas não deixa claro, no documento que estipula sua política de desenvolvimento de acervo, se mantém uma ou mais de uma coleção autônoma e possuidora de características especiais ou com itens que as possuam.

O Sistema de Bibliotecas da Universidade Federal do Ceará divide seu acervo entre as seguintes coleções: nível didático, nível básico ou de lastro, nível de pesquisa, coleção corrente, produção intelectual da instituição e coleções especiais. As diretrizes de formação das coleções especiais são as de "coletar e armazenar tudo o que for publicado pelas edições UFC e Coleção Alagadiço Novo" (UNIVERSIDADE..., 2004b, p. 1), sendo os seus critérios para seleção estabelecidos em um documento detalhado e anexado à política de desenvolvimento do acervo da instituição e complementados pela submissão dos materiais à analise de professores, bibliófilos e bibliotecários que entendam do assunto. As coleções especiais do Sistema de Bibliotecas da Universidade Federal do Ceará são, portanto, compostas pelas obras publicadas pela universidade, pela Coleção Alagadiço Novo e por obras raras, antigas e preciosas. A coleção que reúne a produção intelectual da instituição é gerida como uma coleção diferente das coleções especiais, mas o documento não deixa claro os critérios para a seleção do material que a compõe nem a diferenciação desses em relação aos das coleções especiais.

As Faculdades Porto-Alegrenses- FAPA (2007), em seu documento de política de seleção, difere critérios de seleção para materiais nacionais e estrangeiros que compõem a bibliografia básica para os cursos da instituição, para a bibliografia complementar e/ou de atualização, para materiais em multimídia, para jornais, para coleções particulares e para material de referência (incluindo periódicos científicos). Os materiais são classificados segundo suas peculiaridades no momento de aquisição e seleção e as coleções são formadas seguindo critérios que não consideram essas peculiaridades, não havendo na instituição coleções autônomas constituídas por itens com características peculiares e comuns entre si, até as coleções particulares são adquiridas pela biblioteca de acordo com o assunto e 
distribuídas entre o acervo de circulação geral, e não pelo seu teor histórico e cultural para a instituição ou por terem pertencido a alguma personalidade.

A Política de Desenvolvimento de Coleções do Centro Universitário Ritter dos Reis UNIRITTER (2008, p. 7) faz a seguinte observação sobre as coleções especiais no capítulo sobre seleção: "as coleções especiais e de obras raras seguem critérios próprios de seleção e preservação e aconselha-se a consulta a especialistas para sua seleção", mas dentre as categorias de coleções que compõem o acervo da biblioteca da UNIRITTER não há uma coleção denominada especial, ou mesmo de obras raras.

A Política de Desenvolvimento de Coleções da Biblioteca da Universidade do Estado de Santa Catarina (2004a), na seção que trata da seleção quantitativa, define como materiais a serem selecionados os livros, a coleção de referência, os periódicos, os trabalhos de conclusão de curso e relatórios de estágio, as teses, dissertações e monografias e os materiais especiais. Os materiais especiais são compreendidos como os CD-ROMs, os DVDs, as fitas de vídeo, os mapas e outros, a serem adquiridos segundo demanda e necessidade e seguindo os critérios para seleção de qualquer outro material, quais sejam:

- adequação ao currículo acadêmico e às linhas de pesquisa;

- qualidade do conteúdo;

- autoridade do autor e/ou editor;

- demanda;

- atualidade da obra;

- quantidade (excesso/escassez) de material sobre o assunto na coleção da biblioteca;

- idioma acessível;

- custo justificável;

- número de usuários potenciais que poderão utilizar o material;

- condições físicas do material;

- conveniência do formato e compatibilização com equipamentos existentes.

(UNIVERSIDADE..., 2004a, p. 9-10)

A Biblioteca Acadêmico Luis Viana Filho, do Senado Federal (2007), em seu documento de política de seleção e descarte, define políticas específicas para determinados tipos de itens ou conjuntos de itens, considerando nessas as coleções especiais, as coleções de recursos eletrônicos, as coleções de periódicos, os documentos de autoria de senadores (publicados pelo senado, enquanto do mandato dos autores), as publicações lançadas na biblioteca, as obras impressas pela Secretaria Especial de Editoração e Publicações (SEEP), as obras que possam atualizar ou ser adicionadas à Bibliografia Brasileira de Direito (mantida pela biblioteca), para publicações oficiais (documentos administrativos, regimentos, estatutos, relatórios, informativos, de interesse dos trabalhos legislativos) e separatas de periódicos. 
Todos esses materiais, de alguma forma, diferenciam-se dos demais documentos que compõem coleções da biblioteca e são tratados dessa forma no momento da seleção. A coleção de recursos eletrônicos e multimeios é composta por CD-ROMs, disquetes, periódicos eletrônicos e outros materiais. A coleção de periódicos é composta pelos jornais assinados pela biblioteca e por recortes de jornais mantidos em pastas suspensas, pelos periódicos e por bases de dados via Internet e boletins eletrônicos. Apesar de todos esses documentos e coleções possuírem características que as distingam dos demais, a ponto de serem abordados em capítulo especial na política de coleções da biblioteca, são nomeadas por especiais por essa política apenas as coleções de obras raras e a Biblioteca Depositária.

A Política de Desenvolvimento de Coleções do SENAC do Rio Grande do Sul (2009, seção IV, art. $4^{\circ}$ ) afirma que "o acervo das Bibliotecas deverá conter todo tipo de material informacional, independente de seu suporte físico, que sirva de apoio às atividades de ensino, pesquisa e extensão desenvolvidas pelas Unidades do SENAC/RS.”. O artigo $11^{\circ}$ da Seção VI dispõe sobre a conveniência do formato do documento e da compatibilização desse com os equipamentos existentes na biblioteca, bem como da qualidade visual e auditiva dos materiais especiais como critérios para a seleção de documentos. As coleções especiais e as coleções de obras raras são vislumbradas na política e "seguem critérios próprios de seleção e preservação, aconselhando-se a consulta a especialistas para sua seleção" (Seção VI, artigo $13^{\circ}$ ), mas nenhum critério de fato foi estabelecido na política. O parágrafo $17^{\circ}$ da seção VII afirma que se deve atentar para as obras raras, clássicas ou especiais, as traduções importantes, primeiras edições, os prefácios ou introduções dignos de atenção, anotações ou dedicatórias de notáveis e o valor histórico para a Instituição no momento da doação.

A biblioteca do UNIEURO Centro Universitário, em sua Política de Seleção e Desenvolvimento de Coleção (2007), afirma que seu acervo é formado pelos seguintes tipos de materiais:

a) Obras de referência; b) Enciclopédias, mapas geográficos e históricos e atlas; c) Livros; d) Periódicos (abstracts, revistas especializadas e gerais, jornais etc.); e) Toda produção intelectual da instituição; f) Trabalhos finais de conclusão de curso (independente de sua natureza) produzidos pelo corpo discente; g) Multimeios (DVD, CD-ROM, fitas cassete e de vídeo); h) Outras publicações de interesse da Instituição (UNIEURO, 2007)

Percebe-se que a biblioteca não se preocupou em titular qualquer coleção como especial, mas mantém coleções autônomas dentro de seu acervo de acordo com as semelhanças compartilhadas pelos documentos a partir dos "diversos tipos de materiais" (Idem). 
Para o Sistema de Bibliotecas do Centro Federal de Educação Tecnológica do Rio Grande do Norte - CEFET-RN (2008a), os Materiais especiais (CD-ROM, DVD, fitas de vídeo, mapas, e outros) são compreendidos como um tipo de suporte de informação a ser avaliada no momento da seleção quantitativa, ao lado dos livros, periódicos, coleção de referência, trabalhos de conclusão de curso/relatórios de estágios, teses, dissertações e monografias. O documento que define a política de desenvolvimento de coleções não deixa clara a formação de uma coleção independente ou especial para qualquer tipo de material, sequer para aqueles chamados por ela de materiais especiais.

A Biblioteca Central do Centro de Educação Superior de Blumenau (2003) afirma, em sua Política de Atualização e Expansão do Acervo, que seu acervo é formado pelos seguintes tipos de materiais:

- Obras de referências (almanaques; bibliografias gerais e especializadas; censos estatísticos; dicionários lingüísticos, literários, bibliográficos e especializados; enciclopédias; mapas geográficos e históricos; atlas, etc.);

- Livros;

- Periódicos (abstracts, revistas especializadas e gerais, jornais etc.);

- Todas as publicações editadas pela instituição;

- Trabalhos finais de conclusão de curso (independente de sua natureza) gerados pelo corpo discente;

- Multimeios (CD/DVD-ROM, fitas de vídeo etc.);

- Outras publicações de interesse da Instituição (CENTRO..., 2003).

Não há na política desta biblioteca clareza sobre a distinção de coleções especiais de qualquer tipo em seu acervo.

\subsection{Algumas experiências e visões de promoção e disseminação das Coleções Especiais}

Mais que compreender o que são e como são formadas as coleções especiais, é importante descobrir o que pode ser feito para que essas coleções se tornem visíveis e acessíveis aos usuários que possam ou queiram delas usufruir. Para tanto, foram analisadas experiências de profissionais com coleções especiais em unidades de informação, publicadas e relatadas em periódicos, congressos, entre outros, bem como visões teóricas sobre alguns meios de disseminar e promover as coleções especiais. 
Nem todas as experiências descritas a seguir foram vivenciadas em bibliotecas, mas foram incluídas nessa revisão por tratarem também de iniciativas ou tentativas de, de algum modo, promover as coleções especiais, facilitando o acesso e/ou tornando possível sua disponibilização efetiva, contribuindo assim para este trabalho.

Ferreira (1976, p. 232) examina a situação dos documentos oficiais audiovisuais, fazendo um panorama das iniciativas, ao longo da história, de facilitar o seu acesso e recuperação. Para ela, "o acesso aos documentos audiovisuais é extremamente difícil, perdendo-se fontes de pesquisa da maior importância, por falta de registro e divulgação".

A autora relata terem sido as bibliotecas públicas dos Estados Unidos as primeiras a organizar coleções especiais de registros musicais e cinematográficos, na década de 20 do século passado. A preocupação girava em torno do processamento desses materiais para a sua posterior recuperação. O primeiro catálogo coletivo especializado surgiu em 1939 e foi compilado pelo Comitê de Publicidade da American Library Association. Esse catálogo incluía sugestões de fontes de materiais para uso nas bibliotecas, especialmente em exposições públicas, e abrangia materiais como mapas, tabelas, filmes, diapositivos e fotografias, bem como as informações sobre como e onde obtê-los.

Também é relatada por Ferreira a iniciativa, em 1974, da National Audiovisual Center dos Estados Unidos em publicar o Catalog of United States Government Produced Audiovisual Materials, onde estão listados mais de 4000 materiais especiais, bem como maneiras possíveis para aquisição e aluguel desses materiais.

No Brasil, a autora destaca a iniciativa de elaboração do Índice Corrente de Recursos Audiovisuais. A proposta de tal índice foi apresentada no $2^{\circ}$ Congresso Regional sobre Documentação, realizado no Rio de Janeiro em 1970. Ferreira ressalta que "embora o aspecto da divulgação seja considerado, a ênfase do trabalho está, sem dúvida, voltada para o processamento técnico e a normalização das informações a serem incluídas no Índice” (Idem, p. 239).

Os autores de tal trabalho afirmam que a realização do índice evitará “o isolamento de todos os grupos, com vantagem para o melhor aproveitamento de trabalhos e experiências realizadas com os audiovisuais" (HAMAR; GERMANO, 1970, p. 349). Seu objetivo era reunir informações sobre materiais especiais disponíveis no Brasil, tanto em coleções particulares quanto em coleções institucionais, além de tornar disponíveis possibilidades de consulta, obtenção de cópias e maneiras de utilização. $\mathrm{O}$ objetivo era divulgar o índice internacionalmente, dando enfoque ao Brasil e à America Latina. 
A experiência do Setor de Multimeios da Biblioteca Central Comunitária de Itajaí, do Sistema Integrado de Bibliotecas da Universidade do Vale do Itajaí (UNIVALI BCC/SIBIUN) é relatada por Leber (2008), em artigo sobre o Cineclube Sibiun. Nele, Leber (2008, p. 233) explica que o objetivo do cineclube é

trazer os acadêmicos para dentro da biblioteca, amantes do cinema ou não, para que seja difundida a idéia de uso dos recursos audiovisuais em sala de aula, para a promoção e divulgação da biblioteca, do seu acervo e serviços, e também para proporcionar um espaço voltado à cultura cinematográfica em produção na Universidade.

O Cineclube é parte do Serviço de Ação Cultural da rede de bibliotecas e promove sessões semanais com diferentes títulos predefinidos, sugeridos por professores, usuários ou selecionados por funcionários da biblioteca. O Cineclube exibe filmes cinematográficos, documentários e mostras utilizando títulos do acervo da biblioteca, ou emprestados por professores, alunos, funcionários e locadoras. São disponibilizados textos e/ou sinopses de apoio e, ocasionalmente, debates são promovidos pela própria biblioteca ou por outro setor da universidade. O cronograma de exibições é apresentado semestralmente e as sessões são projetadas nas salas do Setor de Multimeios. A biblioteca também utiliza recursos como cartazes, baneres, e-mails divulgando as sessões, além de notas para a Rádio UNIVALI e a TV UNIVALI. Sessões diárias também são realizadas, exibindo-se filmes do acervo da biblioteca selecionados por colaboradores do Cineclube. Os usuários têm acesso aos cronogramas de exibição através da página web da biblioteca, além de sinopses e outras informações.

A exibição de filmes pelo Cineclube gerou pedidos de reserva por parte de professores para uso das salas e do acervo a fim de exibir filmes para grupos de alunos, além do aumento de uso do acervo do Setor de Multimeios e do número de usuários na biblioteca e no setor, bem como de sugestões de compras e doações. Leber explica que o Cineclube "possibilitou também que os materiais fossem mais reconhecidos como fonte de informação e pesquisa, além de proporcionar para a comunidade uma fonte de cultura e lazer" (Idem, p. 235).

A experiência da biblioteca Alberto Nepomuceno, da Escola de Música da Universidade Estadual do Rio de Janeiro - UERJ, relatada por Brandão, Rocha e Jinkings no artigo Acervo Musical: cultura aberta, direito de todos!, mostra a preocupação das autoras em retirar obras musicais de sua alocação inadequada, bem como catalogar e indexar o acervo para que se tornasse possível a disponibilização de tais obras ao público interessado. $\mathrm{O}$ 
esforço na captação de recursos e no processamento técnico do acervo (especialmente os $75 \%$ dele composto por partituras manuscritas e impressas) demonstra o interesse que se teve em possibilitar o acesso às obras pertencentes à biblioteca Alberto Nepomuceno, buscando-se "desta maneira solucionar e superar ainda o problema de disseminação desta informação valiosa" (Ibidem, p. 6).

A experiência com as coleções especiais da Biblioteca Central Pe. Aloísio Mosca de Carvalho S/J da Universidade Católica de Pernambuco - UNICAP é relatada por Gonçalves, Vidal e Alves (2002, p. 5), que descrevem seus esforços em tratar e organizar os documentos para garantir "o amplo acesso às informações contidas nessa massa documental, beneficiando assim a sociedade como um todo". O relato da experiência da UNICAP deixa clara uma preocupação com a disponibilização das coleções especiais, que até recentemente mantinham seus documentos "apenas bem guardados, quase que escondidos, sem nenhum tratamento ou possibilidade de acesso pelos usuários" (Idem, p. 6). Outras ações como a reestruturação do layout das estantes, sinalização e criação de ambiente para consulta às obras são relatadas e demonstram meios de viabilizar a disseminação das coleções especiais.

A experiência da Biblioteca Joaquim Cardozo, do Centro de Artes e Comunicação da Universidade Federal de Pernambuco/UFPE, com sua Coleção Oficina Guaianases de Gravura, é relatada por Carvalho, Otero e Barbosa (2006). As autoras descrevem as atividades e empreendimentos de identificação e análise do acervo, catalogação do material, conservação, acondicionamento e arquivamento, digitalização de parte significativa do acervo e sua disponibilização na Internet, a partir de uma base de dados. Para elas, "a importância do projeto está também no resgate e visualização do acervo que retrata o trabalho de uma época em que figuram nomes expressivos do cenário artístico nacional" (CARVALHO; OTERO; BARBOSA, 2006, p. 136).

Muitas iniciativas para a disseminação de documentos e coleções especiais, especialmente de obras raras, estão relacionadas à digitalização de exemplares muito significativos ou de coleções inteiras. Um dos exemplos disso é o projeto Overmeer da Biblioteca de Ciências Médicas - Manguinhos, da Fundação Oswaldo Cruz. "A iniciativa de difundir digitalmente as obras raras da instituição iniciou-se em 2000, com a elaboração do 'Projeto Overmeer'." O Projeto consiste na digitalização do acervo de obras raras da Biblioteca de Manguinhos, buscando sua preservação e disseminação, além de enriquecer o patrimônio cultural brasileiro (RODRIGUES, 2007, p. 182).

Cardoso (2008) relata seu trabalho com a digitalização de sumários de periódicos que compunham a coleção especial João Chiarini, do Espaço Memória Piracicabana, realizado no 
decorrer do ano de 2007, demonstrando uma preocupação com a recuperação da informação em meio a acervos especiais desorganizados e não-tratados. Cardoso encara os sumários digitalizados como "instrumentos de pesquisa" que possibilitam menor desgaste dos documentos e poupam tempo dos usuários.

Tosta e co-autores (2007) consideram que a acessibilidade aos documentos, tanto os textuais quanto os não textuais (entendidos pelos autores como especiais), deve ser uma das preocupações do profissional da informação, considerando-se inclusive o grande descaso dos governantes quanto à situação estrutural e funcional dos arquivos, bibliotecas, museus, centros de documentação e outros instrumentos de democratização da informação. Para eles, é necessário repensar formas mais democráticas de se garantir o acesso a documentos. Os autores analisam e refletem sobre a digitalização como uma dessas formas, realizando um trabalho prático de levantamento de coleções especiais em arquivos da cidade de Salvador e suas condições e implicações para a digitalização.

Os autores concluem que a digitalização é uma possibilidade para a democratização dos acervos especiais, mas que, para isso, é necessário que políticas de preservação dos originais sejam estabelecidas e que uma formação mais adequada, voltada às atividades de conversão digital, seja ofertada aos profissionais envolvidos.

A Universidade de São Paulo-USP possui vasto acervo de obras raras e especiais e, recentemente, iniciou um projeto com o objetivo de digitalizar obras selecionadas desse acervo. A Biblioteca Digital de Obras Raras e Especiais "foi criada com o objetivo de divulgar e facilitar o acesso ao conteúdo de um grande número de livros raros ou com características especiais existentes nas diversas bibliotecas da Universidade de São Paulo". O projeto foi empreendido com o auxílio do Governo Federal e com o apoio do Conselho Nacional de Desenvolvimento Científico e Tecnológico - CNPq. O Sistema de Bibliotecas da USP - Sibi/USP, deixa clara, na página da Biblioteca Digital de Obras Raras e Especiais, a importância do empreendimento, que garante “o acesso de estudiosos e leigos a um patrimônio cultural de inegável valor para o desenvolvimento de pesquisas e de intercâmbio de informações entre especialistas e a comunidade em geral" (UNIVERSIDADE..., 2009b).

O Projeto Rede da Memória Virtual Brasileira, empreendido pela Biblioteca Nacional do Rio do Janeiro em parceria com a Financiadora de Estudos e Projetos - FINEP, reúne bibliotecas num mesmo objetivo de automação e disponibilização de seus acervos em formato digital, apoiando-as, inventariando e disseminando a memória brasileira armazenada nas muitas coleções espalhadas pelo país. “A criação e geração de conteúdos digitais inéditos de relevância para a cultura regional e nacional e a sua difusão através do Portal da Rede 
Memória Virtual Brasileira, permitirá a universalização do acesso à diversidade cultural brasileira”. (BIBLIOTECA..., 2009c)

Atualmente são parceiros do Projeto a Universidade do Estado do Rio de Janeiro, o Museu Histórico Nacional, a Fundação Oscar Niemeyer, a Fundação Cultural Curitiba, a Fundação Joaquim Nabuco, a Escola Politécnica da Universidade Federal do Rio de Janeiro, o Clube de Engenharia, o Observatório Nacional, a Fundação Cultural de Blumenau, o Laboratório de Tecnologia da Informação/UFPE, a Fundação Cultural do Pará Tancredo Neves, a Superintendência Estadual de Bibliotecas Públicas de Minas Gerais, a Fundação Casa de Rui Barbosa, o Museu do Índio e o Arquivo Geral da Cidade do Rio de Janeiro. Todas essas instituições estão envolvidas com a digitalização de obras de seus acervos para a sua disponibilização e disseminação.

Algumas preocupações, no que se refere à digitalização de documentos especiais, giram em torno da preservação do conteúdo, pois possibilitar o acesso ao conteúdo digitalizado diminui a necessidade de consultas ao documento original, o que contribui para um menor desgaste de seu suporte físico, que se deteriora com facilidade e rapidez. Há a possibilidade de preservação, mas há também, segundo Nardino e Caregnato (2005), uma mudança nos hábitos de acesso.

As autoras lembram que "a consulta à obra rara esteve sempre condicionada à presença física do pesquisador na biblioteca; as salas que abrigam estes acervos são geralmente lugares fechados, onde ao usuário não é permitido entrar” (Idem, p. 393). A digitalização de documentos raros e especiais possibilita uma facilitação no acesso àquele documento (ou, ao menos, à informação daquele documento), que agora não mais se restringe às limitações de espaço, deslocamento e horário de funcionamento da biblioteca. $\mathrm{O}$ acesso simultâneo também é outra vantagem da disponibilização digital de documentos especiais, pois a mesma obra pode ser consultada por mais de um usuário, não obstante o caráter de unicidade que essa possa ter. As possibilidades de interatividade com o documento também aumentam como, por exemplo, o aumento do zoom, a criação de menus e hiperlinks, o que inova a maneira de lidar com o documento especial e pode trazer à tona novas possibilidades de uso da informação desse documento.

Para Reifschneider (2008, p. 71), “a questão do acesso à obra rara é delicada, já que estamos lidando com algo precioso, muitas vezes único, cuja perda pode ser irreparável". Para o autor, o maior valor de uma obra está no seu uso, ou seja, não há dúvidas da necessidade imprescindível de se disponibilizar e tornar acessível a obra rara. O problema é "como promover acesso às obras raras e preservá-las para que esse acesso seja continuado”. 
Para ele, a digitalização das obras raras pode ser uma boa saída no que se refere à sua disponibilização. No entanto, quando houver interesse no suporte, nos aspectos físicos do objeto, o melhor a fazer é receber o usuário na biblioteca e orientá-lo quanto aos procedimentos de consulta ao acervo especial.

O estudioso Briquet de Lemos (2009) não entende a digitalização de obras e acervos especiais, necessariamente, como uma boa iniciativa. Ele lembra que, em muitos casos, algumas obras são digitalizadas várias vezes por instituições diferentes, utilizando cada uma delas uma quantidade enorme de recursos, que poderia ser disponibilizada para a conservação do original. Para ele, basta uma única digitalização para cada obra rara. Pode-se evitar desperdício de recursos e de tempo, fazendo-se uma pesquisa na Internet e buscando constatar se ela já está digitalizada, a fim de não redigitalizar a obra que já passou por esse processo. $\mathrm{O}$ estudioso compara a atual situação da digitalização de obras especiais com a época áurea da microfilmagem, quando, "por falta de informação e coordenação, muitas obras, principalmente o Diário Oficial da União, eram microfilmadas múltiplas vezes, para alegria das empresas de microfilmagem" (LEMOS, 2009). 


\section{Metodologia}

Este trabalho consiste numa pesquisa exploratória e descritiva. O método utilizado deve-se à falta de pesquisas anteriores sobre o tema, tendo sido, por isso, gerada uma necessidade de seguir o caminho investigativo.

O objeto desta pesquisa são as Coleções Especiais contidas em bibliotecas. Procurouse observar os conceitos e idéias existentes a respeito dessas coleções, bem como experiências institucionais na tentativa de disseminar e promover o acesso a elas. Isso se fez através de revisão de literatura, abrangendo livros, artigos e apresentações em eventos, que proporcionaram visões consolidadas acadêmica e cientificamente sobre as coleções especiais, bem como políticas de desenvolvimento de coleções, que deram acesso a visões particularizadas de algumas instituições sobre o tema.

Além disso, procurou-se coletar dados sobre o tema através da observação pessoal informal in loco, e da exploração de portais da web de bibliotecas que contivessem Coleções Especiais, além da exemplificação de outros meios de disseminação, passíveis de observação ao longo do semestre de elaboração deste trabalho.

Para observar e analisar as páginas da web, foram selecionadas aleatoriamente algumas bibliotecas que contivessem uma divisão, setor ou serviço de Coleções Especiais, e que lhes disponibilizassem, em seus portais na web, algum espaço. As observações e análises foram feitas a partir desses espaços dedicados às Coleções Especiais, ou seja, a partir das páginas na web das referidas divisões, setores ou serviços.

Fez-se necessário seguir determinado método de análise, de modo que se pudesse verificar a disponibilidade de informações consideradas importantes, tais como: divulgação do horário de funcionamento dos serviços e visitas, localização física das coleções, títulos das coleções, seus conteúdos resumidos ou suas descrições, obras de destaque, link para lista de títulos ou pesquisa no catálogo da biblioteca, normas de empréstimo ou consulta local, existência de projeto de digitalização de obras, bem como a visibilidade das páginas das coleções especiais na página principal da biblioteca.

Nas observações in loco, não se seguiu qualquer padrão pré-estabelecido, mas se visitou a biblioteca em seu horário de funcionamento e, em conversa com um profissional responsável pelo setor ou divisão de Coleções Especiais ou por alguma Coleção Especial especificamente, buscou-se entrar em contato com a parte do acervo em foco e com as maneiras como a instituição lida com tal acervo. Procurou-se, também, visitar as estantes e estabelecer algum tipo de familiaridade com os exemplares. A escolha das bibliotecas baseou- 
se no fato de estas possuírem uma ou mais de uma coleção especial e/ou por manterem administrativamente uma divisão ou setor que por elas se responsabilizasse, bem como do fato de serem, por esses motivos, conhecidas no Distrito Federal e também por se mostrarem acessíveis à visitação.

Essas observações in loco levaram a obter uma visão geral das divisões de Coleções Especiais, seus acervos e serviços, e do modo como essas coleções são compreendidas e administradas em diferentes instituições. 


\section{Descrição e análise dos dados}

A partir da metodologia proposta, levantou-se literatura pertinente (presente na revisão de literatura), realizou-se observação informal in loco e foram exploradas páginas na web de bibliotecas que contivessem coleções especiais em seu acervo a partir de uma seleção aleatória de sites.

A observação informal in loco foi feita junto a três bibliotecas do Distrito Federal: Biblioteca Luis Viana Filho do Senado Federal, Biblioteca Central da Universidade de Brasília e Biblioteca Demonstrativa de Brasília. Trata-se de bibliotecas amplamente conhecidas no Distrito Federal, entre outros aspectos, pelas suas coleções especiais. A escolha dessas bibliotecas partiu do conhecimento prévio da autora sobre a existência de importantes coleções em seus acervos. Seguem os comentários sobre essas observações.

\section{Biblioteca Demonstrativa de Brasília - Setor de Multimeios e Periódicos}

Na Biblioteca Demonstrativa de Brasília (BDB), a socióloga Ana Maria da Costa Souza é responsável pela seção de Projetos Especiais, e, na ausência da bibliotecária responsável, respondeu pelo Setor de Multimeios e Periódicos.

O Setor de Multimeios e Periódicos, outrora chamado de Setor de Materiais Especiais, capta, processa e disponibiliza jornais, revistas, CDs, DVDs, fitas de vídeo e livros especiais. O Setor é composto por uma coleção de livros de arte, catálogos de exposições, Coleção Primeiros Passos, hemeroteca, coleção de multimeios, Coleção Elizabeth Bishop com livros e revistas em inglês, além de revistas e jornais correntes. Anteriormente, uma coleção de mapas fazia parte desse Setor, mas a mapoteca foi desativada por defasagem de conteúdo e falta de orçamento para investimentos.

O Setor visitado ocupa uma sala reservada da biblioteca, onde são alocadas as coleções, com exceção da Coleção Elizabeth Bishop, e onde são realizados o processamento técnico e o atendimento ao público. O Setor também conta com uma sala com computadores e acesso à Internet, para uso do material disponível no acervo e para consultas e pesquisas online. A Coleção Elizabeth Bishop fica em uma sala reservada e exclusiva e que recebe o mesmo nome da coleção.

A política para a seleção de materiais para o Setor de Multimeios e Periódicos segue os critérios gerais para todas as coleções da biblioteca, buscando cobrir o maior número 
possível de assuntos com profundidade suficiente para um público geral. As exceções a essa regra se referem aos periódicos - que são selecionados de acordo com a demanda dos usuários -,, aos multimeios - já que todo material multimeio é necessariamente pertencente ao Setor e ao preço - todo livro com preço muito elevado é considerado material especial e alocado na sala reservada ao Setor. As ações e os projetos da BDB são divulgados no site e através de outros meios, mas não há uma divulgação específica relacionada às coleções especiais.

A circulação dos itens do Setor de Multimeios e Periódicos é restrita à consulta local, não sendo possibilitado empréstimo domiciliar nem especial. O usuário, de acordo com sua demanda ao chegar à biblioteca, é conduzido a algum funcionário do Setor de Multimeios e Periódicos e é auxiliado, dentro do possível, segundo o desejo do usuário, que filtra a pesquisa e tenta chegar a um nível de assunto atendível dentro do setor. Geralmente o usuário chega com uma demanda muito específica e nada encontra no catálogo, mesmo que haja algo no acervo. Isso se deve ao fato de que, segundo a socióloga, os usuários não sabem pesquisar em catálogos ou usar o material da biblioteca.

Para Ana Maria da Costa Souza, material especial é todo material não-livro; mas uma coleção especial pode ser formada, inclusive, por livros especiais, por exemplo os caros ou de difícil acesso.

\section{Biblioteca Central da Universidade de Brasília - Divisão de Coleções Especiais}

Na Biblioteca Central da UnB (BCE - UnB), a bibliotecária Lussara Ribeiro Vieira é responsável pela Divisão de Coleções Especiais. Para ela, uma coleção especial é uma coleção de materiais com assuntos de determinada relevância para a instituição, para uma área de conhecimento ou para uma região. Já material especial é o material não-livro: multimeios, partituras, discos, microfilmes, disquetes, entre outros. Ela entende que periódico é um material contínuo - não um livro - mas, como material impresso e muito comum nas bibliotecas, é quase tratado como um livro: está entre livro e material especial, mas não é um material especial. Exige processamento diferenciado, alocação diferenciada. Explica, ainda, que obras raras formam uma coleção especial, mas um livro que faz parte dela não é um material especial, por ser livro.

A BCE possui uma Divisão de Coleções Especiais (DCE), que administra, processa e disponibiliza as coleções formadas por materiais especiais e outras coleções especiais. Seu acervo inclui: Coleção Editora UnB, Coleção de periódicos publicados pela UnB, Coleção 
Cerrado, Coleção Brasília, Acervo de teses e dissertações (anterior a 2005), Coleções de organismos internacionais (OIT, ONU, OMS e outros), Coleções de línguas exóticas, Coleção Estudos Clássicos, Coleção de Multimeios (composta por partituras, VHS, DVD, CDs, Vinil, fitas cassete, rolos de filmes, películas e outros materiais), Mapoteca, Obras Raras e Biblioteca Digital e Sonora.

Administrativamente, a DCE funciona em uma sala no subsolo. Ali está alocada a maior parte das coleções especiais acima citadas. As Obras Raras e a Mapoteca estão alocadas cada uma em salas exclusivas. A Biblioteca possui uma política de seleção e nela há espaço para as coleções especiais.

A promoção das coleções especiais não constitui uma ação primária da biblioteca. No momento da observação, um projeto de divulgação do acervo em VHS, durante as férias de verão, estava em andamento. Visitas orientadas à Coleção de Obras Raras são oferecidas. São agendadas de acordo com a demanda, geralmente de professores, e podem ser marcadas no balcão de referência.

Quando os usuários desejam ter acesso a alguma coleção especial, são orientados no balcão de referência da Biblioteca e já comparecem à Divisão de Coleções Especiais com as informações necessárias em mãos. Com exceção das Obras Raras, o usuário que não sabe especificamente o que deseja ou precisa é conduzido às estantes e orientado até descobrir o item procurado. Na seção de Obras Raras, os usuários são acompanhados por algum funcionário e são orientados a usar luvas, e podem fotografar o que desejam. Há um bibliotecário exclusivo das Obras Raras, treinado e apto a orientar os usuários interessados nessa coleção.

\section{Biblioteca Acadêmico Luiz Viana Filho, Senado Federal}

Na Biblioteca do Senado, a bibliotecária Cláudia Coimbra Diniz, responsável pela Coleção de Obras Raras, acompanhou a observação. Para ela, existe uma diferença entre obras raras e obras especiais e não-raras. As obras raras são as portadoras de características de raridade, bastante conhecidas no meio biblioteconômico. As obras não raras, mas especiais, são as obras autografadas, as que pertenceram anteriormente a pessoas ilustres, as obras luxuosas, as obras comemorativas ou as possuidoras de algum valor para uma instituição. Para Cláudia Diniz, CDs e DVDs não são materiais especiais, pois não têm, segundo ela, nada de especial em seu formato. 
Na Biblioteca Acadêmico Luiz Viana Filho, segundo o documento da política de seleção e descarte, as coleções especiais são as obras raras e as obras publicadas pelo Senado, mas, segundo o panfleto de divulgação por ela distribuído e para a administração cotidiana, essa diferenciação não pareceu clara. Durante a observação, foi dito que há uma equipe liderada por um bibliotecário para cada coleção da biblioteca, desse modo cada profissional fica por saber muito pouco sobre alguma coleção que não seja a de sua responsabilidade. As coleções da biblioteca assim se apresentam segundo panfleto de divulgação: Acervo (o acervo de circulação geral, com 170 mil livros, 11 mil obras de referência e 3800 títulos de periódicos); Coleção de Jornais; Multimeios; Biblioteca Virtual; Coleção de Obras Raras; Coleção Senador Luiz Viana Filho e Depósito Legal das Obras do Senado.

Todo documento que não seja da coleção de Acervo fica em salas especiais. Há uma sala para cada coleção, à exceção da Mapoteca, que é alocada em estantes deslizantes. Há uma política geral de seleção e aquisição da biblioteca, e todos os materiais são alvos dessa política, incluindo as obras raras e todos os outros tipos de materiais. O principal critério, segundo a bibliotecária, é o conteúdo dos documentos. A política em questão foi analisada neste trabalho.

A Biblioteca possui um planejamento para uma ação de marketing. No momento da observação, o marketing geral da biblioteca girava em torno da distribuição dos folhetos. $\mathrm{Na}$ biblioteca não é prioridade promover suas coleções porque já funciona e atende no limite de sua capacidade. O usuário que deseja consultar qualquer coleção que não seja a do acervo geral deve procurar o serviço de referência, onde será orientado. O usuário que quer consultar obras raras deverá escolher uma única obra, não poderá entrar na sala de obras raras, mas irá a uma sala reservada para consulta, usando luvas e acompanhado por um funcionário. O mesmo acontece para consultas à Coleção Luiz Viana Filho. Outras coleções têm seu acesso menos restrito, mas não podem ser emprestadas, à exceção dos Multimeios.

No momento da observação, tentou-se um acesso às coleções especiais, todavia, nenhuma orientação foi obtida por parte de qualquer dos três bibliotecários procurados, sob a justificativa de que tal auxílio seria de responsabilidade de outro profissional. Desse modo, a visita limitou-se a uma conversa com a bibliotecária responsável pelas obras raras, não resultando em contato direito com as coleções.

Das bibliotecas visitadas, embora fosse esta a que mais promovesse a disseminação de suas coleções especiais através de panfletos, catálogos impressos, e outros meios, foi a que menos proporcionou a efetivação do acesso tão amplamente divulgado. 


\section{Análise exploratória das páginas na web}

A exploração das páginas na web consistiu em acessar algumas instituições aleatoriamente selecionadas e em descrever seus recursos.

A Internet torna possível o acesso a informações sobre os acervos de diversas bibliotecas. Muitas delas disponibilizam em suas páginas na web espaços reservados às suas coleções especiais, ou às divisões administrativas que por elas se responsabilizam. Considerou-se que a análise dessas páginas fosse importante para que se descobrisse sua instrumentalidade para a divulgação e disseminação das coleções especiais.

Conforme especificado na metodologia, segue a descrição das páginas visitadas. Ao final os resultados das análises foram sistematizadas em um quadro, para melhor visualização e comparação:

\section{Sistema de Bibliotecas da Universidade Federal de Campinas - Unicamp}

De acordo com a página analisada, o Sistema de Bibliotecas da Unicamp possui uma Área de Coleções Especiais, composta por obras raras e coleções especiais e que "reúne, preserva, e provê acesso a obras raras e coleções especiais. Seu acervo é utilizado para pesquisa e ensino de graduação, pós-graduação e público em geral". A Biblioteca define que sejam as coleções especiais aquelas compostas por acervos pertencentes outrora a intelectuais e doadas ou por ela compradas. Algumas dessas coleções de intelectuais contêm obras raras e fundos bibliográficos. Há ainda outras coleções compostas por obras raras e que não possuem vínculo com as coleções de intelectuais.

O Sistema de Bibliotecas da Unicamp disponibiliza em sua página na web um espaço para a Área de Coleções Especiais. Nessa página são disponibilizadas informações sobre o acervo, sobre a identificação e catalogação das obras, serviços oferecidos pelo setor, links relacionados aos temas das obras raras, das coleções especiais e da preservação de acervos, localização física das coleções, horário de funcionamento, endereços, telefones e e-mail para contato.

Dentre os serviços oferecidos pelo setor estão: serviços de referência e instrução para uso das coleções; acesso local para documentos raros, escassos, frágeis, documentos anteriores a 1930 e exemplares com autógrafos, dedicatórias e grifos de celebridades; reprodução de microfilmes através de leitora digitalizadora de microfilmes; localização de 
microfilmes de obras raras em outras bibliotecas; autorização de serviço de fotografia local e de microfilmagem terceirizado, com a assistência do conservador da coleção; informações para usuários por acesso remoto (correio, fax, e-mail); preparação de apresentações, exposições e publicações.

Além disso, a página informa que a Área de Coleções Especiais participa dos bancos de dados Acervus (relativo aos acervos da Unicamp), Unibibli (relativo aos acervos das universidades estaduais paulistas), da Base de Dados P19 (Periódicos do século XIX, mantida pela Biblioteca Nacional do Rio de Janeiro, da Rede Bibliodata, do Catálogo Coletivo do Patrimônio Bibliográfico Nacional - CPBN, mantido pela Biblioteca Nacional do Rio de Janeiro, e do Indicador das Bibliotecas Brasileiras de Acervo Antigo. A participação desta área nos bancos de dados acima citados muito divulga as obras raras e especiais pertencentes ao acervo especial do Sistema de Bibliotecas da Unicamp.

O acervo de coleções especiais é composto pelas coleções: Sérgio Buarque de Holanda, Alexandre Eulálio, Aristides Candido de Melo e Souza, Peter Eisenberg e José Albertino. O acervo de obras raras é composto pela Coleção Brasiliana, que reúne obras dos séculos XVI, XVII, XVIII. XIX e XX; pelos Fundos Bibliográficos Alexandre Eulálio e Antonio Candido; bem como pelo manuscrito em pergaminho de cantos gregorianos, ilustrados com iluminuras, datado do século XV.

Algumas ilustrações e estampas são exibidas na página da Área de Coleções Especiais, acompanhadas de informações sobre autor, data, título, obra onde pode ser encontrada e coleção à qual essa obra pertence. No momento da análise da página, uma exposição virtual sobre a Coleção Sérgio Buarque de Holanda estava disponível, em homenagem ao centenário do nascimento do ilustre.

Não foram localizadas informações sobre as normas de utilização e/ou empréstimo das coleções, nem sobre projetos de digitalização das obras, embora seja possível verificar ilustrações digitalizadas no momento em que se entra na página. Também não se localizou um link que levasse a algum catálogo ou lista de títulos, embora as coleções estejam bem descritas e seus assuntos bem especificados. ${ }^{3}$

\footnotetext{
3 A página da Área de Coleções Especiais do SBU-Unicamp está disponível em: <http://www.sbu.unicamp.br/bccl/colesp/HPCE100.HTM>. A página da área de Coleções Especiais está acessível através do link "endereços e horários”, visível no menu da página principal do SBU.
} 


\section{Biblioteca Central da Universidade de Brasília - BCE}

A página da biblioteca disponibiliza informações sobre a divisão, horários de funcionamento e atendimento, telefone e e-mail para contato, bem como características das coleções, seguido de sua localização física. Nenhuma obra de destaque das coleções foi evidenciada na página em questão. Seu acervo inclui: Coleção de Multimeios (MTM), Mapoteca (MAP), Obras Raras (OBR), Coleção de Organismos Internacionais e Assuntos Especiais (OAE) e Biblioteca Digital e Sonora (BDS).

Não há link na página da $\mathrm{BCE}^{4}$ para o catálogo da biblioteca. Quando se tenta pesquisar no catálogo da biblioteca, percebe-se que nem todos os documentos pertencentes a essas coleções especiais estão processados tecnicamente para que possam ser recuperados.

Há um selo no canto direito da página principal da BCE que dá acesso a uma página da Biblioteca Digital e Sonora ${ }^{5}$. Nessa página há informações sobre a coleção, sobre o projeto que a viabiliza, sobre legislação da área de direitos autorais e de acessibilidade, créditos da equipe que trabalha junto à coleção, telefone e $e$-mail para contato e sugestões, amostra do acervo e espaço para cadastramento e login de usuários. As normas de utilização do acervo estão presentes no Termo de Compromisso, disponível para download na página. Não foram localizadas as informações sobre a localização física da coleção ou link para pesquisa no catálogo da Biblioteca, mas foram recuperadas informações sobre todos os documentos pertencentes a essa coleção que se tentou pesquisar no catálogo.

\section{Biblioteca do Ibero-Amerikanisches Institut Preussischer Kulturbestz (Instituto Ibero- Americano-IAI)}

A Biblioteca do Ibero-Amerikanisches Institut Preussischer Kulturbestz (Instituto Ibero-Americano-IAI), em sua página, afirma que "as coleções especiais podem ser consideradas como uma espécie de interface para onde convergem as atividades realizadas no âmbito da biblioteca, pesquisa e gestão de eventos". Para essa instituição, os documentos que

\footnotetext{
4 A página na web da Divisão de Coleções Especiais da BCE está disponível em: <http://www.bce.unb.br/index.php?option=com_content\&view=article\&id=18\&Itemid=35>. Foi possível acessá-la a partir da página principal, no menu "Sobre a BCE", através do link "Estrutura".

${ }^{5}$ A página da Biblioteca Digital e Sonora está disponível em: 〈http://bds.bce.unb.br/index.html〉.
} 
compõem suas coleções especiais são únicos e dão expressiva contribuição à preservação cultural, permitindo uma aproximação multifacetada das regiões ibero-americanas através dos projetos, pesquisas, publicações e exposições que se tornam possíveis pela existência e acesso desses documentos.

As seguintes coleções formam o acervo de coleções especiais da biblioteca do IAI: fonoteca, coleção de filmes, mapoteca, coleção de cartazes, arquivo de recorte de jornais e arquivo fotográfico. A página na web da biblioteca ${ }^{6}$ dá informações sobre os títulos das coleções e seus conteúdos, sobre os serviços relativos a cada uma das coleções, horários de atendimento, normas para utilização, localização física, telefone e e-mail para contato, algumas obras de destaque e links para pesquisa no catálogo da biblioteca ou em inventários. Alguns dos materiais que compõem essas coleções especiais estão inseridos no catálogo online, permitindo a recuperação remota de informações sobre esses documentos. Os demais documentos ainda não processados, esclarece a Biblioteca, no sítio, estão disponíveis em catálogos e inventários especiais para consulta local.

Há no menu esquerdo da página da Biblioteca um link para a agenda de visitas guiadas ao Instituto e à sua biblioteca. As visitas regulares acontecem uma vez por semana e delas podem participar qualquer pessoa que desejar, bastando comparecer no horário divulgado. As visitas coletivas devem ser agendadas, e são realizadas em diferentes línguas e sob enfoques temáticos diferenciados, de acordo com a demanda.

Não foram localizadas informações sobre projetos de digitalização das obras especiais. No entanto, há a possibilidade de reprodução de alguns documentos, e as instruções para tal são dadas nos textos que descrevem as normas de uso de cada coleção.

A Biblioteca do IAI traz à luz ainda as chamadas Coleções Especializadas, presentes nos acervos de várias bibliotecas "em que são compilados materiais literários e informações seja sobre determinadas disciplinas seja sobre determinados países, regiões ou culturas para colocá-los à disposição da ciência". Essas coleções são mantidas com o apoio da Fundação Alemã para a Investigação Científica, e a Biblioteca do IAI é uma delas, sendo responsável pela coleção especializada 7.36 Ibero-América.

\footnotetext{
6 A página na web das Coleções Especiais do Instituto Ibero-Americano está disponível em: $\langle$ http://www.iai.spk-berlin.de/pt/biblioteca/colecoes-especiais.html〉. A página que dá acesso às informações sobre as Coleções Especializadas está disponível em: <http://www.iai.spk-berlin.de/pt/biblioteca/colecoesespecializadas.html>. Foi possível chegar facilmente a ambas as páginas através do menu da página principal da biblioteca, onde os links estão intitulados "Coleções Especiais" e "Coleções Especializadas", de forma direta e clara.
} 


\section{Biblioteca Central de Grogoatá da Universidade Federal Fluminense - BCG/ UFF}

A Biblioteca Central de Grogoatá, do Núcleo de Documentação da Universidade Federal Fluminense (BCG-NDC, UFF) possui as seguintes coleções especiais: coleções particulares de Alair Gomes, jornalista e fotógrafo; de Maria Jacintha, teatróloga e crítica; coleção Estudos Americanos; Estudos Galegos e as coleções que compõem as obras raras: a coleção de Ismael Coutinho, O Pasquim e a coleção Bezerra de Menezes. A página na web da biblioteca dá acesso a informações sobre serviços, horários de funcionamento e contatos, mas relativos à biblioteca em geral, e não exatamente às coleções especiais. Não se encontrou informações sobre a localização física das coleções, além do endereço do prédio da biblioteca. Tampouco se encontrou descrições das coleções, normas para sua utilização ou informações sobre digitalização das obras ${ }^{7}$.

\section{Biblioteca Universitária da Universidade Federal de Santa Catarina - BU/UFSC}

A Biblioteca Universitária da Universidade Federal de Santa Catarina (BU-UFSC) disponibiliza em sua página na $w e b^{8}$ acesso às informações sobre o seu Serviço de Coleções Especiais. O Serviço está dividido em oito coleções: Coleção Especial de Santa CatarinaCESC, Coleção Especial de Teses e Dissertações - CETD, Coleção Especial de Publicações da Universidade Federal de Santa Catarina - CEPU, Coleção Especial de Obras RarasCEOR/CERC, Coleção Especial de Microformas - CEM, Coleção Especial de Material Cartográfico - CEMC e Coleção Especial de Audiovisuais - CEAV.

Essas coleções são descritas sucintamente na página, mas nenhuma obra de destaque foi citada. Dados sobre as obras que constituem as coleções podem ser recuperadas no catálogo on-line da biblioteca facilmente, mas a informação de que essa recuperação pode ser feita não foi encontrada na página do Serviço de Coleções Especiais, não foi encontrado qualquer link para o catálogo.

A página oferece informações sobre localização do Serviço e das coleções, horários de atendimento, regras para reserva dos auditórios e salas especiais e telefone/e-mail para contato

\footnotetext{
${ }^{7}$ As obras que compõem as coleções especiais da BCG estão disponíveis para recuperação através do catálogo on-line do NDC, em: <http://www.ndc.uff.br/argonauta/>. A página web que dá informações sobre as coleções especiais da BCG está disponível em: 〈http://www.ndc.uff.br/bcg.asp〉. Todas as informações sobre as coleções especiais estão na página principal da biblioteca, não um espaço reservado apenas a elas.

${ }^{8}$ Disponível em: <http://www.bu.ufsc.br/>.
} 
e fornece pequenas descrições sobre a natureza de cada coleção. Essa página foi localizada através do link que dá acesso às explicações sobre a estrutura da biblioteca, o qual, por sua vez, localiza-se no menu principal da página da $\mathrm{BU}^{9}$.

Na página principal da BU há um link que dá acesso a uma base de dados de obras raras digitalizadas, intitulada Biblioteca Universitária-Obras Raras, mas não há informações sobre a base ou as obras nela contidas, sua seleção e localização do original. Há apenas um espaço para buscas que, quando realizadas com recuperação positiva, dão acesso aos documentos digitalizados para visualização e download. Há, no rodapé da página, um link sobre o projeto que deu origem à base (Projeto Sidie), mas as tentativas de acessá-lo não foram bem sucedidas ${ }^{10}$.

\section{Fundação Biblioteca Nacional - BN}

A Fundação Biblioteca Nacional - BN não possui um setor de Coleções Especiais, talvez pelo seu caráter de Biblioteca Nacional, o que permite que qualquer documento de seu acervo seja classificado como especial. As páginas de suas coleções diferenciadas foram analisadas utilizando-se a navegação pelo menu principal, começando-se pelo link "Por dentro da BN" e se chegando às diferentes coleções, já que não se encontrou um espaço reservado apenas a elas dentro do sítio da BN. Esse link dá acesso a explicações sobre cada uma das coleções que compõem o acervo da BN, apresenta suas descrições, características e obras de destaque. Apenas não se conseguiu chegar às descrições da coleção de manuscritos, já que o link que daria acesso a elas apenas levava ao catálogo. Além das coleções Obras Gerais e Referência, a biblioteca possui as coleções Iconografia, Música, Periódicos, Obras Raras, Manuscritos e Cartografia.

Há, no menu principal, o link "Catálogos" que leva a catálogos específicos para cada coleção. O link "Serviços a leitores" informa sobre o Atendimento à Distância, serviço oferecido pela biblioteca, dando acesso a formulário de pedido de atendimento, bem como a endereços, telefones e e-mail para contato. Da mesma forma, o link "Reprodução do acervo" dá acesso a informações sobre as normas e tabelas de preços para os serviços de microfilmagem, fotografia, cópia eletrostática e reprodução sonora. Algumas publicações da

\footnotetext{
${ }^{9}$ Disponível em: <http://www.bu.ufsc.br/modules/conteudo/index.php?id=40>

10 A página Biblioteca Universitária - Obras Raras (Projeto Sidie) está disponível em: < http://www.literaturabrasileira.ufsc.br/bdbu/>.
} 
BN são vendidas através da página, com acesso pelo link "Loja do livro". Dentre essas publicações, estão catálogos e guias sobre as coleções da própria BN. O link "Visita guiada" encerra as opções dispostas em "Serviços a leitores" e dá acesso a informações sobre os horários de visitas e sobre a necessidade de agendamento, bem como o telefone para contato.

Os horários de atendimento e as normas para a utilização das coleções estão disponíveis através do link "Atendimento", no link no menu "Por dentro da BN". Informações sobre projetos de digitalização estão disponíveis através do link "Biblioteca digital". A localização física de cada uma das coleções não está clara em qualquer das páginas que descrevem as coleções, embora maiores informações sobre algumas dessas localizações possam obtidas nas normas de utilização ${ }^{11}$.

Quadro comparativo dos resultados das análises das páginas web de bibliotecas

\begin{tabular}{|c|c|c|c|c|c|c|c|c|}
\hline / / & 1 & 2 & 3 & 4 & 5 & 6 & 7 & 8 \\
\hline $\begin{array}{l}\text { UNICAMP- } \\
\text { Área de } \\
\text { Coleções } \\
\text { Especiais }\end{array}$ & $X$ & $X$ & $X$ & $X$ & $\mathrm{~N}$ & $\mathrm{~N}$ & $\mathrm{~N}$ & $\mathrm{X}$ \\
\hline $\begin{array}{l}\text { BCE } \quad- \\
\text { Divisão de } \\
\text { Coleções } \\
\text { Especiais }\end{array}$ & $X$ & $X$ & $X$ & $\mathrm{~N}$ & $\mathrm{~N}$ & $X$ & $\mathrm{~N}$ & $X$ \\
\hline $\begin{array}{l}\text { IAI } \\
\text { Coleções } \\
\text { Especiais }\end{array}$ & $X$ & $\mathrm{X}$ & $X$ & $X$ & $X$ & $X$ & $\mathrm{~N}$ & $\mathrm{X}$ \\
\hline
\end{tabular}

\footnotetext{
${ }^{11}$ A página da BN está disponível em: <http://www.bn.br/portal/?nu_pagina=1 >.
} 


\begin{tabular}{|c|c|c|c|c|c|c|c|c|}
\hline 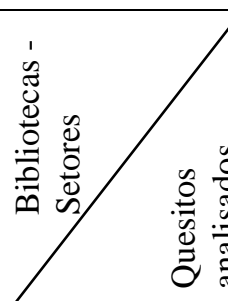 & 1 & 2 & 3 & 4 & 5 & 6 & 7 & 8 \\
\hline $\begin{array}{l}\text { BCG/ UFF } \\
\text { - Coleções } \\
\text { Especiais }\end{array}$ & $X$ & $\mathrm{~N}$ & $\mathrm{~N}$ & $\mathrm{~N}$ & $X$ & $\mathrm{~N}$ & $\mathrm{~N}$ & $X$ \\
\hline $\begin{array}{l}\text { BU/UFSC- } \\
\text { Serviço de } \\
\text { Coleções } \\
\text { Especiais }\end{array}$ & $X$ & $\mathrm{~N}$ & $X$ & $\mathrm{~N}$ & $\mathrm{~N}$ & $\mathrm{~N}$ & $X$ & $X$ \\
\hline $\mathrm{BN}$ & $\mathrm{X}$ & $\mathrm{X}$ & $\mathrm{X}$ & $X$ & $\mathrm{X}$ & $\mathrm{X}$ & $\mathrm{X}$ & $\mathrm{X}$ \\
\hline
\end{tabular}

Legenda:

Quesitos analisados na metodologia:

1 - Divulgação dos horários de funcionamento dos serviços e visitas;

2 - Informações sobre a localização física das coleções;

3 - Informações sobre os títulos das coleções, seus conteúdos resumidos ou suas descrições;

4 - Informações sobre as obras de destaque;

5 - Presença de link para lista de títulos ou para pesquisa no catálogo da biblioteca;

6 - Informações sobre as normas de empréstimo ou consulta local;

7 - Indicação de existência de projeto de digitalização de obras;

8 - visibilidade das páginas das coleções especiais na página principal da biblioteca.

$\mathrm{X}$ - os quesitos analisados estão presentes na página

$\mathrm{N}$ - os quesitos analisados não foram encontrados na página

\section{Outras maneiras de promoção e disseminação}

Além das páginas na web, sabe-se da possibilidade de outros meios de se disseminar e promover as coleções especiais. Alguns desses outros meios foram observados neste estudo exploratório, e seguem compilados e analisados.

Os catálogos coletivos são um modo muito eficaz para a divulgação de alguns documentos. A visibilidade que os catálogos coletivos dão a algumas obras no âmbito regional é muito maior que a que teriam se permanecessem registradas apenas em catálogos locais. Os catálogos coletivos de redes de informação, como a Bibliodata, a Rede Pergamum, entre outros, são de muita utilidade para a recuperação de informações sobre obras especiais, permitindo sua localização e também a economia de tempo do usuário-pesquisador, que pode acessar vários acervos num único espaço. O Catálogo Coletivo Nacional ganha destaque 
como catálogo de publicações seriadas, que pode dar visibilidade a publicações periódicas de todo tipo, de maneira facilitada.

Há também os catálogos coletivos especializados em obras especiais, como o Catálogo Coletivo do Patrimônio Bibliográfico Nacional, com obras do século XV, XVI, XVII, XVIII e XIX - CPBN, mantido pelo Plano Nacional de Recuperação de Obras Raras - PLANOR, da Biblioteca Nacional do Rio de Janeiro, e o Catálogo Coletivo da Associação de Bibliotecas Nacionais da Ibero-América - ABINIA. Tais catálogos especializados permitem a economia de tempo na pesquisa, recuperação e localização. Também permitem que um usuário explore o campo das obras especiais, reconhecendo a existência e disponibilidade dessas obras ao passear por esses catálogos.

O Projeto Rede da Memória Virtual Brasileira, da Biblioteca Nacional do Rio de Janeiro, reúne diversas bases de dados que dão acesso a fontes primárias de informação digitalizadas, incluindo obras raras e antigas, fotografias, periódicos, dentre outros formatos. Nesse caso, não se trata exatamente de um catálogo coletivo, mas de um sistema de informação que tem como objeto a memória cultural brasileira e que reúne acervos de instituições depositárias de documentos significativos e importantes para o tema.

A distribuição de catálogos impressos também é uma forma muito comum de divulgação das coleções especiais. Esses catálogos, elaborados exatamente com o intuito de disseminar obras e coleções para um público específico, distinguem-se em sua produção e acabamento, chamando a atenção para as coleções especiais de uma determinada instituição. Esses catálogos são geralmente distribuídos pela biblioteca que os produz, em eventos promovidos por ela ou dos quais ela participa. Exemplos recentes desses são o Catálogo de Obras Raras da Câmara dos Deputados, o Catálogo de Obras Raras da Biblioteca Municipal Mário de Andrade, o Catálogo da Obras Raras da Biblioteca Pública do Estado da Bahia, o Bibliotheca Universitatis: catálogo de obras raras e especiais dos acervos da USP, o Catálogo de Obras Raras e Especiais da Biblioteca de Manguinhos, Catálogo das Coleções Especiais e Acervos Museológicos da USP.

Um exemplo recente de distribuição de catálogos como esses, como ação de promoção de coleções especiais, pôde ser observado no evento Semana do Bibliotecário, promovido em março de 2009 pela Biblioteca Nacional de Brasília em cojunto com o Conselho Regional de Biblioteconomia da $1^{\mathrm{a}}$. Região, quando foram distribuídos, dentre outros, o Catálogo da Fundação Alexandre de Gusmão, do Ministério das Relações Exteriores. Algumas bibliotecas disponibilizam tais catálogos em suas páginas na web, para download ou consulta. 
A distribuição de panfletos em eventos para o público externo ou na própria biblioteca é uma maneira simples e muito eficaz de promover a disseminação de qualquer serviço ou produto. Um panfleto geral, que contenha informações breves sobre a estrutura da biblioteca, seus horários de funcionamento, locais de atendimento, coleções e serviços é um instrumento comum, mas que contribui para informar o usuário sobre a biblioteca de um modo como poucos outros instrumentos o fazem. Informar sobre as coleções especiais nesses panfletos é de muita valia para disseminar a existência delas e seu uso por parte dos usuários. Panfletos para divulgação exclusiva de coleções especiais com apresentação das suas características, regras para uso, modos de acesso e localização podem evidenciá-las e potencializar seu uso.

A distribuição desses panfletos é tão importante quanto sua confecção. Dentro da biblioteca, pode-se dispô-los em algum local de grande movimentação para os usuários que desejarem, ou, ainda, distribuí-los em mãos. Durante eventos, tanto os promovidos pela biblioteca, quanto pela instituição a qual esta pertence, ou qualquer outro evento do qual a biblioteca venha participar, há sempre a oportunidade para a distribuição dos panfletos, o que muito contribui para a divulgação dos serviços da biblioteca e, em especial, de suas coleções especiais. Como exemplo, pode-se citar a distribuição dos panfletos com informações sobre a Biblioteca da Presidência da República durante o evento da Semana do Bibliotecário, no corrente ano.

A realização de exposições é uma maneira interessante de fazer conhecida uma coleção especial, seja de obras raras, seja da coleção particular de alguma personalidade, seja de fotografias, de gravações sonoras ou outros, as exposições são de muito valor para a divulgação das coleções especiais e das obras que as compõem na biblioteca, bem como dos serviços relacionados a elas. As exposições possibilitam não só o encontro do usuário com a informação, como também potencializam o uso dela por aqueles que já a haviam encontrado. As exposições também aguçam o interesse de leitores, pesquisadores e estudantes por novas áreas do conhecimento ou por novas obras, até então ainda não evidenciadas para eles.

As próprias exposições já são uma forma de uso do acervo que proporciona informações novas aos usuários, não apenas a divulgação de sua existência. Um exemplo a ser ressaltado, neste caso, é o da exposição das obras raras da Biblioteca Acadêmico Luis Viana Filho, do Senado Federal, realizada em comemoração aos 180 anos da biblioteca, no ano de 2006, quando foram expostas obras como o livro Novus Orbis, datado de 1633, e a coleção Flora Brasiliensis, publicada entre 1840 e 1906. Outro exemplo é o da exposição com artefatos, obras e poemas de Cassiano Nunes, na ocasião da abertura do Espaço Cassiano Nunes, realizada pela Biblioteca Central da Universidade de Brasília, no ano de 2008. 
A abertura dos acervos para visitas, especialmente as guiadas, dissemina as coleções, coloca-as em uso e abre novas possibilidades de acesso à informação aos usuários que delas participam. As visitas são, elas mesmas, um evento cultural que a biblioteca promove, assim como as exposições que são, também, uma forma de uso. Apenas esses fatos valem a abertura dos acervos aos usuários e a preparação de funcionários como guias. Mas, além disso, as visitas proporcionam aos usuários a possibilidade de conhecerem a biblioteca, seus documentos e as informações que podem disponibilizar. $\mathrm{O}$ ato de caminhar entre as estantes, em qualquer biblioteca, é tão corriqueiro quanto a leitura, e é esse ato que permite, muitas vezes, ao usuário, o contato com o que a biblioteca tem a oferecer. No caso das coleções especiais, os acervos estão, muitas vezes, alocados separadamente, restritos e com o acesso limitado. As visitas às estantes das coleções especiais permitem que aquele passeio corriqueiro pelo acervo, passe a acontecer também entre os documentos diferenciados.

No caso de acervos que contenham filmes, a realização de sessões de projeção são uma boa maneira de divulgação do acervo e dos serviços relacionados a ele. As sessões podem ou não ser seguidas de debates ou podem estar vinculadas a outras atividades coletivas e culturais. O fato é que elas colocam à mostra para o público tanto a existência de uma coleção de filmes na biblioteca quanto as suas possibilidades de uso. Exemplos de iniciativas como essas são a do Cineclube empreendido pelo Setor de Multimeios da Biblioteca Central Comunitária de Itajaí, da UNIVALI e também as sessões que foram oferecidas pela Biblioteca Central da Universidade de Brasília, inclusive a divulgação do acervo em VHS durante as férias de verão do corrente ano. 


\section{Conclusão}

Foi possível perceber que as coleções especiais são compreendidas de maneiras diferentes. Muitas coleções especiais são formadas a partir do foco da diferenciação de seus documentos formadores em relação ao livro impresso comum, mas esse não é necessariamente o principal fator considerado no momento de sua formação. Ocorrem vezes em que este fator sequer é levado em consideração.

O fato é que os documentos que formam as coleções especiais são necessariamente diferentes em algum aspecto. Mesmo livros impressos podem apresentar tais fatores de distinção. Há, para cada instituição (e até para cada profissional que nela trabalha), uma definição criada por ela mesma a partir de estudos, reflexões e experiências.

Verificaram-se alguns pontos comuns entre as várias concepções para as coleções especiais. Comumente, por exemplo, as coleções especiais são associadas às coleções de obras raras. Percebeu-se também que é comum entre as bibliotecas a distinção entre coleção especial e material especial.

Verificou-se que a maior parte das bibliotecas analisadas possui, em sua Divisão de Coleções Especiais, uma coleção ou mesmo uma subdivisão de materiais especiais, o que contribui para a difusão da idéia de que o conceito coleções especiais inclui os materiais eletrônicos, magnéticos, ópticos e imagéticos de todo tipo. Foi, ainda, possível verificar que os materiais especiais são também chamados de multimeios ou de audiovisuais, e podem ser compreendidos como meios complementares de se dar suporte à informação.

Foi possível constatar que muitas bibliotecas tratam como coleções especiais aquelas que compuseram, em algum momento, as bibliotecas particulares de pessoas de renome para alguma área do conhecimento ou para um contexto histórico-cultural.

Quanto às políticas de desenvolvimento de coleções, pôde-se perceber que muitas delas contemplam as coleções especiais, em alguma parte de seu conteúdo. A presença e as diretrizes para as coleções especiais variam muito de política para política, especialmente nos critérios para a seleção. Não se observou, na maioria dos casos, uma preocupação específica com essas coleções. São, em geral, relegadas a um segundo plano.

Quando se estuda e observa o acervo para a categorização de determinados documentos ou conjuntos de documentos como especiais, possibilita-se sua valorização e também sua promoção de acordo com suas características singulares, e não de acordo com as 
características gerais do acervo da biblioteca. Dessa forma, o estabelecimento de coleções especiais contribui para prever, de maneira mais clara, as ações de desenvolvimento de coleções, de desbaste e de descarte, bem como para preservar, de forma significativa, itens ou conjuntos inteiros de itens que não se preservariam, talvez de maneira alguma, se não fossem considerados como especiais.

Percebeu-se que as coleções especiais mais recorrentes nas bibliotecas são: conjuntos de materiais especiais/multimeios; coleções de obras raras; gibitecas; Coleções formadas a partir de um enfoque de uso específico, não sob o enfoque usual do desenvolvimento de coleções de acervo geral; bibliotecas particulares de personalidades de renome num contexto regional ou nacional ou no contexto de uma área do conhecimento; bibliotecas particulares de personalidades relacionadas à instituição onde se localiza a biblioteca; coleções de valor histórico/culturais para o país/cidade/estado; coleções de valor histórico para a instituição; depósitos legais; mapotecas; documentos arquivísticos, quando em uma biblioteca; documentos oficiais e governamentais; documentos estrangeiros.

Foi possível concluir que as coleções especiais são aquelas que fogem às regras do fluxo diário de informações dentro de uma biblioteca, e que, no entanto, contribuem para o cumprimento de missão por ela estabelecida. São coleções que complementam os serviços primários ali oferecidos e que enriquecem o leque de fontes de informação que esta disponibiliza.

Pela diferenciação natural existente entre os vários tipos de unidades de informação, documentos que seriam de livre acesso para o público, em uma biblioteca, são considerados como especiais em outra, sendo administrados, processados, alocados e disponibilizados de uma maneira particular. Coleções especiais para uma unidade de informação não são tão especiais para outras. Os livros antigos, os manuscritos, os materiais especiais (não-livros, multimeios, audiovisuais, entre outros) e até os periódicos são, a priori, especiais e acabam por se ajuntarem uns com os outros, devido às suas características comuns, formando coleções especiais.

Estabelecidas como especiais, a grande questão é compreender o que é possível fazer para que essas coleções se tornem visíveis e acessíveis a um público potencial. No trabalho de enumeração dos instrumentos de disseminação e promoção das coleções especiais, verificouse que ações muito simples podem se mostrar muito eficazes. Verificou-se, ainda, que as páginas das bibliotecas na Internet são um importante meio de divulgação de seus acervos especiais, bem como dos serviços relacionados a eles. 
A importância das Coleções Especiais é inegável no contexto da disseminação da informação. Os documentos especiais carregam características que os tornam fontes inigualáveis de informações, e que muito contribuem ou podem contribuir para a pesquisa e o avanço em diversas áreas do conhecimento. É necessário que as Coleções Especiais estejam disponíveis e acessíveis ao público usuário, bem como o é que se tornem conhecidas e maximizadas em seu uso.

A diferenciação das coleções especiais pode ter como consequências uma alocação dos documentos distante do acervo geral, sua não visualização pelos usuários num primeiro momento, a necessidade de intermediação entre documento e usuário, limitações nos horários para acesso aos documentos. Há que se pensar que tomar a decisão de se criar ou administrar uma coleção diferenciada dentre o acervo de uma biblioteca pode criar barreiras que dificultem o acesso do usuário ao documento que procura. Muitas vezes, inclusive, essas barreiras são o que se procura no momento da criação de uma coleção especial.

Essas consequências, porém, podem ser encaradas como uma nova oportunidade dentro da biblioteca. O esforço em fazer conhecidas dos usuários as coleções especiais é sempre compensado pelo uso dessas e pela satisfação do usuário em encontrar uma informação diferenciada.

As páginas da web possibilitam o acesso à informação sobre as coleções especiais mesmo às pessoas que se encontram fisicamente distantes ou impossibilitadas de comparecer pessoalmente à biblioteca. Dessa forma, elas se mostraram como um instrumento eficaz para que o objetivo de promover e disseminar fosse atingido. As páginas das bibliotecas proporcionam visibilidade a seus serviços e produtos, transpondo barreiras geográficas e possibilitando que sejam conhecidas em qualquer parte.

Sua ação é relativamente simples: informar que a biblioteca possui algumas coleções diferenciadas, que possuem determinadas características e algumas obras que se destacam; que estão localizadas em uma determinada área da biblioteca que está aberta ao público em um determinado horário e que possui algumas normas para o uso.

Tão importante quanto criar esses espaços para as coleções especiais dentro das páginas das bibliotecas é lhes dar visibilidade na página principal. Das páginas analisadas, poder-se-ia tomar como bons exemplos de disseminação as do Sistema de Bibliotecas da UNICAMP, com seu espaço para a Área de Coleções Especiais, e a do Ibero-Amerikanisches Institut Preussischer Kulturbestz e sua biblioteca com Coleções Especiais e Coleções Especializadas. Em ambas, se encontrou quase todos os quesitos procurados durante a análise para este trabalho, descritos na metodologia. 
A página da Área de Coleções Especiais do SBU-UNICAMP é facilmente visualizada a partir da página principal do SBU, embora isso não ocorra talvez para o usuário que visita a página pela primeira vez. Informações sobre as coleções, sobre os serviços oferecidos pela área, além de outras informações que se relacionam ao tema das coleções especiais e raras estão disponíveis e muito enriquecem, não só o seu espaço na web, mas também a própria área na visão do usuário.

Destaque ainda maior ganha a página das Coleções Especiais do IberoAmerikanisches Institut Preussischer Kulturbestz. Praticamente todas as informações procuradas no momento da análise foram encontradas, com exceção de informações sobre projetos de digitalização das obras. O link para o espaço reservado às coleções especiais na página é facilmente visto, e a navegação é facilitada pelo menu sempre visível que possibilita acessar informações sobre as diferentes coleções sem que seja necessário voltar a uma primeira página. As coleções ganham, cada uma, um espaço, e não apenas uma descrição breve. Nesses espaços, suas obras e características são descritas, bem como suas normas para utilização. Há, em cada um deles, um quadro com os telefones e $e$-mail para contato relativos àquela coleção em especial, e também o link para a pesquisa no catálogo, bem como orientações de como fazê-la. Há também uma agenda de visitas guiadas, o que é um diferencial em relação às demais páginas analisadas.

Percebeu-se que muitas das ações realizadas em função da preocupação com a disponibilização de coleções especiais giraram em torno da própria seleção e processamento técnico. Ações primárias da Biblioteconomia, que não são especificamente direcionadas a documentos diferenciados, foram, em alguns momentos, a solução para a recuperação desses, bem como para a sua acessibilidade. A simples ação do tratamento técnico pode resultar no encontro entre a coleção especial e o seu público.

Constatou-se que a digitalização dos documentos é de grande valia para a disseminação e o acesso aos acervos especiais. A digitalização das obras e a criação de bibliotecas digitais para sua recuperação e uso são de grande valor para o acesso à informação contida nesses documentos. A biblioteca digital permite a consulta aos documentos sem as interferências de deslocamento e horário de atendimento da biblioteca, e também a preservação do original, na medida em que diminui o número de vezes em que esse é consultado e entra em contato com fatores de deterioração. Além disso, outras vantagens são facilmente observadas, como o acesso simultâneo à mesma obra e a interatividade digital entre usuário e documento. $\mathrm{O}$ acesso aos documentos especiais torna-se facilitado no contexto da digitalização, não há a burocracia comum nos procedimentos para acesso pessoal aos 
documentos especiais, tendo como consequência, um maior número de pessoas entrando em contato com um documento em um tempo muito menor.

Uma questão que se levantou em relação à digitalização das coleções especiais se refere, nesse caso, não ao acesso à informação, propriamente dita, mas ao seu suporte. Um documento pode ser definido como a união entre a informação e seu suporte. Quando há acesso à obra especial digitalizada, tem-se, na verdade, acesso à informação da obra original o que seria suficiente para muitos usuários. Todavia essa informação se apresenta em um novo suporte: o que se acessa é um novo documento.

O acesso ao suporte também deve ser garantido, mesmo que restritamente - já que há a necessidade de conservação -, mas deve ser garantido. A digitalização de obras especiais não deve servir como justificativa para a restrição total e permanente dos acervos, mas, pelo contrário, os usuários devem ser orientados a procurar a digitalização como mais uma maneira de acesso aos documentos especiais, com vistas, inclusive, à preservação do suporte.

As novas possibilidades de acesso não devem excluir as antigas. $\mathrm{O}$ acesso ao suporte é, não apenas complementar quando no contato com a obra, mas imprescindível em alguns casos. Nos casos em que o interesse está no suporte como artefato ou quando há a exigência de acesso ao documento como fonte primária de informação, o contato com a versão digitalizada de uma obra não basta. Muitas vezes, a informação que se procura está nas folhas do papel usado, nas linhas da encadernação, no couro da capa, nos negativos originais de uma fotografia.

Quanto às observações in loco, foi possível concluir que mesmo procurando pessoalmente os serviços de coleções especiais de uma biblioteca, nem sempre o acesso é garantido. Uma das bibliotecas visitadas é muito conhecida por suas ações de marketing. No entanto, o que se pôde observar é que o serviço tão bem divulgado não conta com a mesma qualidade no momento de efetivar-se. Ficou demonstrada uma total falta de correspondência entre a divulgação da existência de valiosos documentos e a acessibilidade a eles.

Pôde-se encontrar coleções especiais muito ricas em instituições com escassos recursos, bem como facilidade de acesso, como no caso da Biblioteca Demonstrativa de Brasília, o que demonstra que o profissionalismo é mais imprescindível que os próprios recursos financeiros. Mesmo na abundância destes, os resultados são fracos e ineficazes se não contar com a iniciativa e a visão características de um profissional comprometido em efetivar o encontro entre a informação e o usuário.

Na BCE-DCE foi possível constatar a existência de coleções especiais de diversos tipos, o que enriqueceu muito a presente pesquisa, já que a observação destas coleções 
ampliou a visão que se tinha por ocasião do início do tratamento do tema. As coleções da DCE abrangem obras raras, coleções de livros especiais, mapas, multimeios.

As limitações deste estudo se referem à exiguidade do tempo permitido dentro do semestre letivo a ele dedicado. Além disso, a escassez bibliográfica - que, por um lado, foi motivadora para a pesquisa, por outro, constituiu-se em elemento dificultador para sua execução. O caráter exploratório da pesquisa também pode ser apontado como delineador de limites. Por esse motivo este trabalho não esgota o assunto, mas conclui propondo outras investigações que poderão enriquecer o conhecimento já acumulado e buscar soluções para a problemática.

Sugere-se uma inclusão de forma mais abrangente desta temática como parte dos conteúdos e discussões no curso de Biblioteconomia desta instituição de ensino superior. Não apenas no que se refere a tratar das conceituações, mas também das necessidades de disseminação e acesso, da sua importância cultural e histórica e do bibliotecário como mediador na formação, tratamento e disponibilização das coleções especiais. 


\section{Referências}

ABATTI, Rosana Chaves. Obras raras em bibliotecas jurídicas. Florianópolis: UDESC, 2006. Monografia apresentada à Universidade do Estado de Santa Catarina - UDESC, como parte dos requisitos para obtenção do título de especialista em Gestão de Bibliotecas. Orientadora: Prof. Ms. Noêmia Schoffen Prado. Disponível em: <http://www.tj.sc.gov.br/cejur/estudopesquisas/monografias/obras_raras_rosana_chaves_abatt i.pdf>. Acesso em: maio 2009.

ANDRADE, Diva; VERGUEIRO, Valdomiro. Aquisição de materiais de informação. Brasília: Briquet de Lemos, 1996.

AURÉLIO Buarque de Holanda Ferreira. Novo dicionário da língua portuguesa. Rio de Janeiro: Nova Fronteira, 1995.

BAPTISTA, Dulce Maria. História do livro e das bibliotecas: glossário. Material didático distribuído e utilizado durante as aulas da disciplina História do Livro e das Bibliotecas do segundo semestre do ano de 2008, no Departamento de Ciência da Informação e Documentação da Universidade de Brasília.

BIBLIOTECA NACIONAL DO RIO DE JANEIRO. PLANOR. Abínia. Disponível em: http://catalogos.bn.br/planor/abinia.html. Acesso em: 14 jun. 2009a.

BIBLIOTECA NACIONAL DO RIO DE JANEIRO. PLANOR. Planor. Disponível em: <http://catalogos.bn.br/planor/planor.html>. Acesso em: 14 jun. 2009b.

BIBLIOTECA NACIONAL DO RIO DE JANEIRO. O Projeto Rede da Memória Virtual Brasileira. Disponível em: <http://catalogos.bn.br/redememoria/projeto.html>. Acesso em: 20 maio 2009c.

CARDOSO, Rafael de Paula. Coleções Especiais João Chiarini: um instrumento de pesquisa para o Espaço Memória Piracicabana. In: MOSTRA ACADÊMICA UNIMESP, 6., 2008, Piracicaba. Anais... Piracicaba: Universidade Metodista de Piracicaba, 1994. Disponível em: <http://www.unimep.br/phpg/mostraacademica/anais/6mostra/4/35.pdf>. Acesso em: 20 maio 2009. 
CARVALHO, Maria Auxiliadora. OTERO, Maria Mercedes Dias Ferreira, BARBOSA, Josefa Pereira. Acesso e preservação da Coleção Oficina Guaianases de Gravura. Informação \& Sociedade: Est., João Pessoa, v. 16, n. 2, p. 133-137, jul./dez. 2006.

CARVALHO, Tereza Cristina Oliveira Nonatto de; VAL, Marta Regina da Silveira Ribeiro do. Coleções especiais da biblioteca central/UNICAMP: preservando a memória, relato de experiência. In: SEMINÁRIO NACIONAL DE BIBLIOTECAS UNIVERSITÁRIAS, 13., 2004. Natal. Anais... Natal: UFRN, 2004.

CENTRO DE EDUCAÇÃO SUPERIOR DE BLUMENAU. Política de atualização do acervo da biblioteca central do CEBLU - Centro de Educação Superior de Blumenal. Blumenau, 2003.2 Disponível em: <servicos.capes.gov.br/arquivos/avaliacao/estudos/dados1/2005/41001010/019/2005_019_41 001010044P7_Proposta.pdf>. Acesso em: 3 fev. 2009.

CENTRO FEDERAL DE EDUCAÇÃO TECNOLÓGICA DO RIO GRANDE DO NORTE. SISTEMA DE BIBLIOTECAS DO CEFET-RN. Política de formação e desenvolvimento de coleções. Natal, 2008a. Disponível em: 〈www.cefetrn.br/conteudo/arquivos/desenvolvimentocolecoes-corrigido-1.pdf/download〉. Acesso em: 12 mar. 2009. Documento elaborado por Clediane de Araújo Guedes, Joel de Albuquerque Melo Neto, Maria Ilza da Costa, Sandra Nery da Silva Bigois, Sônia Maria dos S. Araújo, Tércia Maria S. de M. Marques.

CENTRO UNIVERSITÁRIO RITTER DOS REIS - UNIRITTER. Política de desenvolvimento de coleções. Porto Alegre, 2008. Disponível em: <www.uniritter.edu.br/biblioteca/downloads/regimento_interno_das_bibliotecas.pdf>. Acesso em: 14 fev. 2009.

COLLISON, Robert L. The treatment of special material in libraries. Londres: Aslib, 1957.

CONSELHO NACIONAL DE ARQUIVOS - CONARQ. Subsídios para a implantação de uma política municipal de arquivos: o arquivo municipal a serviço dos cidadãos. Rio de Janeiro: Conarq, $2000 . \quad$ Disponível em: <www.portalan.arquivonacional.gov.br/Media/subsidios.pdf>. Acesso em: 16 maio 2009. 
DIAS, Maria Matilde Kronka; PIRES, Daniela. Formação e desenvolvimento de coleções de serviços de informação. São Carlos: Edufscar, 2003.

FACUldADE METROPOLITANA DE BELO HORIZONTE. Política de desenvolvimento de acervo. Disponível em: <http://www.metropolitanabh.coc.com.br/arquivos/pdea.pdf>. Acesso em: 20 fev. 2009.

FACULDADES PORTO-ALEGRENSES. Política de desenvolvimento de coleções da biblioteca central. Porto Alegre, 2007. Disponível em: <www1.fapa.com.br/folder/biblioteca/politica2008.pdf>. Acesso em: 11 fev. 2009.

FERREIRA, Vera Cristina. Documentação Oficial Brasileira em forma não-bibliográfica. Revista de Biblioteconomia de Brasília, v. 4, n. 2, p. 231-265, jul./dez. 1976.

FONSECA, Edson Nery da. Introdução à biblioteconomia. Brasília: Briquet de Lemos, 2007.

GLOSSÁRIO de Termos Biblioteconomicos. Disponível em: <http://www.ipleiria.pt/portal/sdoc?p_id=96901>. Acesso em: 07 maio 2009.

GLOSSÁRIO Geral de Ciência da Informação. Disponível em: <http://www.cid.unb.br/publico/setores/100/123/sistema/m0039015.htm>. Acesso em: 13 maio 2009a.

GONÇALVES, Cristiane Alberto; VIDAL, Luciana; ALVES, Luciana. Organização, tratamento e disponibilização de coleções especiais: a experiência da UNICAP. In: SEMINÁRIO NACIONAL DE BIBLIOTECAS UNIVERSITÁRIAS, 12., 2002, Recife, $\begin{array}{llll}\text { Anais... } & \text { Recife: } & \text { UFPE, } & \text { Disponível }\end{array}$ <http://www.sibi.ufrj.br/snbu/snbu2002/abstract/30.a.htm>. Acesso em: 15 maio 2009.

HAMAR, Alfredo Américo; GERMANO, Fernão Stella Rodrigues. Índice corrente de recursos audiovisuais. In: CONGRESSO REGIONAL SOBRE DOCUMENTAÇÃO, 2. REUNIÃO DA FIF/CLA, 9., 1970, Rio de Janeiro. Anais... Rio de Janeiro: IBBD, 1970, p. 349-356. 


\section{INSTITUTO BRASILEIRO DE INFORMAÇÃO EM CIÊNCIA E TECNOLOGIA.}

CATÁlogo COLETIVO NACIONAL. Catálogo Coletivo Nacional (CCN). Disponível em: <http://www.ibict.br/secao.php?cat=CCN>. Acesso em: 22 maio 2009.

LEBER, Alexsander. Cineclube Sibiun, muito além de uma videoteca: relato de experiência. Revista ACB: Biblioteconomia em Santa Catarina, Florianópolis, v. 228 13, n. 1, p. 223-238, jan./jun., 2008. Disponível

em: <http://revista.acbsc.org.br/index.php/racb/article/view/551/676>. Acesso em: 22 maio 2009.

LEMOS, Briquet de. Re: USP - Obras raras digitalizadas. [mensagem do grupo Bib_virtual]. Mensagem recebida por: <sonia.boeres@gmail.com>. Em: 30 jan. 2009.

MASON, Donald. A primer of non-book materials in libraries. London: Association of assistant librarians - Section of the Library Association, 1958.

MICHAELIS: moderno dicionário da língua portuguesa. São Paulo: Melhoramentos, 1998.

MILANESI, Luís. Biblioteca. Cotia: Ateliê Editorial, 2002.

MINISTÉRIO DA EDUCAÇÃO. Programa Nacional de Bibliotecas Universitárias. Compra de material bibliográfico para bibliotecas universitárias brasileiras. Brasília: MEC, 1991.

NARDINO, Anelise Tolotti Dias; CAREGNATO, Sônia Elisa. O futuro dos livros do passado: a biblioteca digital contribuindo na preservação e acesso às obras raras. Em Questão . Porto Alegre, v. 11, n. 2, p. 381-407. jul./dez. 2005.

OCLC. O Conselho de Membros da OCLC discute semelhanças e diferenças nas bibliotecas que compõem a cooperativa global. Disponível em: <www.oclc.org/americalatina/pt/news/releases/200843.htm>. Acesso em: 18 fev. 2009.

PEROTA, Maria Luiza Loures Rocha. Multimeios: seleção, aquisição, processamento, armazenagem, empréstimo. 4. ed. Vitoria: Edufes, 1997.

REIFSCHNEIDER, Oto Dias Becker. A importância do acesso às obras raras. Revista Iberoamericana de Ciência da Informação, v. 1, n. 1, jan./abr. 2008. 
RODRIGUES, Jeorgina Gentil. O espelho do tempo: uma viagem pelas estantes do acervo de obras raras da biblioteca de Manguinhos. Perspectivas em ciência da informação, v. 12, n. 3, p. 180-194, 2007. set./dez. Disponível em: <http://www.eci.ufmg.br/pcionline/index.php/pci/article/viewFile/155/8>. Acesso em: 11 mar. 2009.

RODRIGUES, Márcia Carvalho. Como definir e identificar obras raras? Critérios adotados pela Biblioteca Central da Universidade de Caxias do Sul. Ciência da Informação, Brasília, v. 35, n. 1, p. 115-121, jan./abr. 2006.

SANT'ANA, Rízio Bruno. Critérios para a definição de obras raras. Revista Online Biblioteca Prof. Joel Martins, Campinas, v. 2, n. 3, p. 1-18, jun. 2001. Disponível em: <http://www.bibli.fae.unicamp.br/revbfe/v2n3jun2001/art01.pdf>. Acesso em: 16 fev. 2009.

SENAC RIO GRANDE DO SUL. Da política de desenvolvimento de coleções. Disponível em: <http://www.senacrs.com.br/2007/personal/200852/16535.pdf>. Acesso em: 15 fev. 2009.

SENADO FEDERAL. Biblioteca Acadêmico Luiz Viana Filho. Política de seleção e descarte da biblioteca do Senado Federal. Brasília, 2007. Disponível em: 〈www.senado.gov.br/sf/BIBLIOTECA/documentos/Politica_de_Selecao_da_Biblioteca.pdf>. Acesso em: 17 fev. 2009.

SILVA, Elisabeth Monteiro. Origem, formação e desenvolvimento das coleções raras e especiais do Colégio Pedro II - Rio de Janeiro. In: Congresso Brasileiro de Biblioteconomia e Documentação, 19., 2000. Porto Alegre: Proceedings. Porto Alegre: Centro de eventos da PUCRS. Disponível em: <http://dici.ibict.br/archive/00000720/01/T061.pdf〉. Acesso em: 17 fev. 2009.

SILVA, Neusa Cardim da; DIB, Simone Faury; CAAMANO, Adriana Campos Jaña. Coleções Especiais: acessibilidade e preservação da memória. In: CIBERÉTICA: simpósio internacional de propriedade intelectual, informação e ética, 2., 2003. Florianópolis. Anais... Florianópolis, 2003. p. 1-8. Disponível em: <http://www.ciberetica.org.br/trabalhos/anais/2253-e1-53.pdf>. Acesso em: maio 2009. 
SOUZA, Cleonice Aparecida de; BERNARDI, Frei Orlando; BUENO, Maria de Fátima Guimarães. O Acervo da Biblioteca de Obras Raras (CDAPH-USF). Bol. CDAPH, Bragança Paulista, v. 3, n. 1, p. 53-62, jan./jun. 2002. Disponível em: $<$ http://www.saofrancisco.edu.br/biblioteca/obrasraras/uploadAddress/ObraRaraArtigo001\%5 B1125\%5D.pdf>. Acesso em: 20 maio 2009.

STUMPF, Ida Regina Chitto. Passado e futuro das revistas científicas. Ciência da Informação, v. 25, n. 3, p. 383-386, set./dez. 1996. Disponível em: <http://revista.ibict.br/index.php/ciinf/article/viewFile/463/422>. Acesso em: 20 maio 2009.

TOSTA, Lívia F. et al. Conteúdos informacionais de coleções especiais e arquivos permanentes sob arquivos permanentes sob guarda de instituições públicas em Salvador: digitalizar é democratizar? In: ENCONTRO NACIONAL DE ENSINO E PESQUISA DE INFORMAÇÃO, 7., 2007. Salvador, UFBA, 2007. Disponível em: <http://www.cinform.ufba.br/7cinform/soac/papers/ac58080bb9269df3b3c945ffb752.pdf>. Acesso em: 20 maio 2009.

UNIEURO Centro Universitário. Política de Seleção e Desenvolvimento de Coleção. 2007. Disponível em:

<http://www.unieuro.edu.br/downloads_2005/biblioteca_desenvolvimento.pdf > Acesso em: 14 fev. 2009.

UNIVERSIDADE DE SÃO PAULO. Sistemas de Bibliotecas. A Biblioteca Digital de Obras Raras e Especiais. Disponível em: <http://www.obrasraras.usp.br/>. Acesso em 15 jun. 2009b.

UNIVERSIDADE DE SÃO PAULO. SISTEMA INTEGRADO DE BIBLIOTECA DA USP. Bibliotecas do SIBi/USP. Caderno de estudos, 7. São Paulo: SIBi/USP, 1998.

UNIVERSIDADE DO ESTADO DE SANTA CATARINA. PRÓ-REITORIA DE ENSINO. BIBLIOTECA UNIVERSITÁRIA. Política de desenvolvimento de coleções da biblioteca universitária da UDESC. Florianópolis, 2004a. Disponível em: <www.bu.udesc.br/download/Potc_desenv_colec.pdf〉. Acesso em: 16 fev. 2009.

UNIVERSIDADE FEDERAL DO CEARÁ. Política para o desenvolvimento do acervo para o Sistema de Bibliotecas da Universidade Federal do Ceará. Fortaleza, 2004. Disponível em: 
<www.biblioteca.ufc.br/PDFS/PolitdeDesenvolvimentodoAcervo.pdf〉. Acesso em: 15 fev. 2009.

VERGUEIRO, Waldomiro. Seleção de materiais de informação: princípios e técnicas. Brasília: Briquet de Lemos, 1995.

WEIHS, Jean Riddle; LEWIS, Shirley; MACDONALD, Janet. Nonbook materials: the organization of integrated collections. Ottawa: Canadian Library Association, 1973. 